\title{
ACOUSTIC CUES FOR THE PERCEPTION OF TONES OF DISYLLABIC NOUNS IN EDO
}

\author{
Victor E. Omozuwa \\ University of Benin, Nigeria
}

Most studies on speech perception, with particular reference to the perception of tones, explained this phenomenon mainly from the auditory point of view. Many questions were therefore left unanswered with regard to the mechanisms involved in the perception of tone. This paper attempts to explain this phenomenon from an acoutic standpoint using recorded disyllabic Edo nouns. It reveals in particular that certain acoustic cues are indispensable for an Edo speaker/hearer in the perception of tones of disylabic nouns, the form and the direction of change of $F_{0}$ variation being the most important. $F_{0}$ is realized in different ways for a given speaker depeinding on the tone pattern as well as the frequency zone characteristic of each of the two basic tonemes, High and Low.

\section{Introduction}

In this paper the various acoustic cues used by Edo speakers/hearers in the perception of tones of disylabic nouns are considered. Edo has two distinctive tones, High and Low, combined in the following manners in disyllabic nouns: V́CV́, V̀CV̀, V̀CV́ and V́CV̀.

Studies by Wescott [1962, 1965], Amayo [1976], Omozuwa [1987a, 1987b], Lhote et al. [1986], among others, show that

(a) sequences of High tones on contiguous syllables are realized on the same pitch level;

(b) sequences of Low tones on contiguous syllables are realized not on the same pitch level but as a short downglide (a case of successive lowering of like tones); 
(c) a Low tone immediately following a High tone is realized as a Falling tone since the Low tone assimilates to the level of the High tone preceding it before its characteristic downglide;

(d) a Low tone preceding a High tone is realized as a low level tone (in physical terms).

The purpose of this paper is to determine the acoustic cue(s) used by Edo speakers/hearers in the perception of the basic tonemes, High and Low, in a given tone pattern.

\section{Experimental Procedures}

This investigation was carried out in three stages. In the first stage, a list consisting of the English translation of 28 Edo disylabic nouns ( 7 different nouns for each of the four tone patterns - cf. list of test words in APPENDIX I) organized in random order was read by a female Edo speaker. The 28 test words were recorded by means of a magnetic tape recorder (a Revox B77 MK II high fidelity stereo tape recorder), a glottometer, and subsequently analysed logarithmically by a melody analyser and graphically by an oscillograph (a two-channel Oscillomink Recorder).

In the second stage, the recorded items were played back to a group of eight listeners from five different linguistic groups in a purely listening/repetition task. The purpose of making non-Edo speakers repeat Edo words was merely a means of simulating Edo tones in the absence of appropriate equipment for speech synthesis. Thus, the "mistakes" made in the production of Edo tones by the non-Edo speakers will serve as a basis for the interpretaton of the perceptual cues for the perception of tones in such Edo nouns. The repetitions by each of the eight listeners were also recorded by means of a magnetic tape, a glottometer, and subsequently analysed by a melody analyser connected to an oscillograph which gives the graphical representation of the analysed signal. This exercise thus provided a second list of $224(8 \times 28)$ tokens for further analysis. Table 1 in APPENDIX II shows the fundamental frequency $\left(\mathrm{F}_{0}\right)$ values and duration of seven V́VV́ words pronounced by a female Edo native speaker (ED) and eight non-Edo speakers from five different linguistic groups: 1 Yoruba native speaker (YB); 1 Ika native speaker (IK); 1 Hausa native speaker (HS); 3 French native speakers (two females: a phonetician and musicologist $\left(\mathrm{FR}_{1}\right)$, a speech therapist $\left(\mathrm{FR}_{2}\right)$; and a male speaker and non-linguist $\left(\mathrm{FR}_{3}\right) ; 2$ native speakers of Cantonese Chinese $\left(\mathrm{CH}_{1}\right.$ and $\mathrm{CH}_{2}$, both phoneticians).

In the third stage of the investigation, the lsit of 224 tokens was presented to ten Edo native speakers/hearers who were asked to write down in English the meaning of each test item presented to them. This is a purely linguistic perception exercise in which the listeners use their previous knowledge of their language in assessing 
which of the productions/repetitions are acceptable or non-acceptable utterances in Edo.

1.1. Presentation of results, and discussion. The acoustic and perceptual results of each tone pattern considered in this investigation will be presented separately. For each tone pattern all the productions/repetitions by each of the eight listeners from five different linguistic groups accepted by the native speakers/hearers are classified separately from those productions/repetitions rejected with the goal of assessing, from the acoustic tracings, the acoustic cue(s) necessary for accepting or rejecting a given utterance in Edo. The acoustic properties of the accepted items for each tone pattern are compared with those of the rejected items.

The $F_{0}$ values for each syllable of each test word were taken at three points: at the beginning of the $\mathrm{F}_{0}$ realization $\left(\mathrm{F}_{0} \mathrm{i}\right)$, at a point two-thirds of the $\mathrm{F}_{0}$ realization $\left(F_{0} 2 / 3\right)$, and at the end of the $F_{0}$ realization, $F_{0} f$. $F_{0}$ values are expressed in Hertz $(\mathrm{Hz})$ while duration is expressed in milliseconds $(\mathrm{ms}) . \mathrm{F}_{0} \mathrm{~m}$ represents the mean value of $\mathrm{F}_{0}$ variation for each syllable. Two asterisks before the abbreviations for a given speaker shows that that word pronounced by that speaker was unanimously rejected by Edo speakers/hearers in the perception test.

\subsection{Interpretation of acoustic results.}

1.2.1. Perception of a sequence of high tones on disyllabic nouns of the $\mathbf{V} C \dot{V}$ type. Fundamental frequency $\left(\mathrm{F}_{0}\right)$ values in Table 1 show that in sequences of High tones on disyllabic nouns (this is also true for polysyllabic nouns), a High tone is perceived only if the tone on the first syllabic peak, $V_{1}$, is realized on the same pitch level, i.e. in the same frequency zone as the tone on the second syllabic peak, $V_{2}$, independently of variations in the duration of the $F_{0}$ realization (there is usually no marked difference in the mean relative intensity for such contiguous High toned syllables). The physical realization of a High tone in Edo in terms of $\mathrm{F}_{0}$ variation is

(a) absence of $F_{0}$ variation from the beginning to the end of the $F_{0}$ realization for a given High toned syllable (cf. the word [úko] 'gourd' pronounced by ED and $\mathrm{FR}_{1}$ )

or

(b) a gradual rise from the beginning to the end of the $F_{0}$ realization, i.e. $F_{0} f \geq F_{0} i$ (cf. the word [úkó] pronounced by $\mathrm{YB}, \mathrm{IK}, \mathrm{CH}_{1}$, and $\mathrm{CH}_{2}$ ). 
Results of this experiment also show that a V́CV́ sequence is automatically perceived as a VCV́ tone sequence if the direction of change of $F_{0}$ variation on the first syllabic peak is falling, i.e. $\mathrm{F}_{0} \mathrm{f}$ is less than $\mathrm{F}_{0} \mathrm{i}$ (cf. the word [úkó] pronounced by $\mathrm{FR}_{2}$ and $\mathrm{FR}_{3}$ ). In addition, the tone sequence is perceived as a Rising tone followed by a High tone if the value at a point $2 / 3$ of the $F_{0}$ variation is more than the $F_{0} i$ of the first syllabic peak but less than its $F_{0} f$ and the $F_{0} i$ of the second syllabic peak (cf. the words [ágó 'tin' and [ága] 'chair' pronounced by HS, or the word [úku] 'praise name for the king' pronounced by $\mathrm{HS}, \mathrm{FR}_{2}$, and $\mathrm{FR}_{3}$ ).

Our investigation further revealed that a $1 / 4$ tone difference between the end point of the $F_{0}$ variation on the first syllabic peak and the beginning of the $F_{0}$ variation on the second syllabic peak is not perceptually significant in the perception of High tones in a V́CV́ sequence. This is probably why the word [èko'] 'Lagos' pronounced by $\mathrm{FR}_{1}$ was perceived as [ékó] (?) by Edo listeners. In the pronunciation of this word by $\mathrm{FR}_{1}, \mathrm{~F}_{0}$ variation is nil on each of the two syllabic peaks but in absolute terms the difference between the $\mathrm{F}_{0} \mathrm{f}$ of the first syllabic peak and the $F_{0} i$ of the second syllabic peak is $1 / 4$ of a musical tone.

1.2.2. Perception of tones of disyllabic nouns of the $\mathbf{V} C \dot{V}$ type. A low tone is perceived on the first syllabic peak if the difference between the $F_{0} f$ value of $V_{i}$ and the $F_{0} i$ value of $V_{2}$ is more than $1 / 4$ of a musical tone. In other words a $\bar{V} C \dot{V}$ word is perceived in Edo only if the difference between $F_{0} f$ of the first syllabic peak and the $\mathrm{F}_{0} \mathrm{i}$ of the second syllabic peak is more than a $1 / 4$ of a tone (cf. Table 3 in APPENDIX II for the $F_{0}$ realization of the VCV word types in Edo).

1.2.3. Perception of a sequence of low tones on disyllabic nouns of the $\mathbf{V} \mathbf{C V}$ type. In a sequence of Low tones on disyllabic nouns, a Low tone is realised on the first syllabic peak either as a Low level tone (cf. the $F_{0}$ values for the word [ùgò] 'name of a village' pronounced by $\mathrm{ED}, \mathrm{YB}$, and $\mathrm{FR}_{1}$ in Table 2), in which case the difference between the $F_{0} f$ of the first syllabic peak and its $F_{0} i$ is nil, or generally as a slightly falling tone (cf. the $\mathrm{F}_{0}$ values for the same word pronounced by IK, $\mathrm{HS}, \mathrm{CH}_{1}$ and $\mathrm{CH}_{2}$ in Table 2) in which case the $\mathrm{F}_{0} \mathrm{f}$ of the first syllabic peak is more than the $\mathrm{F}_{0} \mathrm{i}$ of the second syllabic peak. In both cases, the Low tone on the second syllabic peak cannot be realized physically as a low level tone in Edo but as a falling contour with a steeper gradient (cf. $\mathrm{F}_{0}$ values for all speakers in Table 2). If the low tone on this syllabic peak, i.e. $V_{2}$, is realized physically as a level tone a VCV́ sequence is likely to be perceived if the $F_{0} f$ of the Low tone on $V_{1}$ is less than its $F_{0} i$, while a V́CV́ sequence is likely to be perceived if the 
difference between the $\mathrm{F}_{0} \mathrm{f}$ and the $\mathrm{F}_{0} \mathrm{i}$ of $\mathrm{V}_{\mathrm{i}}$ is nil. Further perceptual tests using synthesized materials are needed to support these claims.

It should be noted that for the same speaker, the $F_{0}$ values of the first syllable of the V̀CVे tone pattern is very close to the $\mathrm{F}_{0}$ values of the first syllable of the V́CV́ tone pattern. This has no effect on the perception of tones of these two word types since the direction of the $\mathrm{F}_{0}$ realization of the two tone patterns is basically different (cf. §§1.2.1, 1.2.3).

It is also in this sequence of homotonous Low tones that $\mathrm{F}_{0}$ variation is directly proportional to variation in intensity. In other words, intensity (I) varies with $\mathrm{F}_{0}$, the intensity at the end of a $\grave{V} \grave{V}$ sequence being less than the intensity at the beginning of the sequence since the direction of change of $F_{0}$ on the first syllabic peak is the same (generally) as that of the second syllabic peak.

1.2.4. Perception of tones of disyllabic nouns of the V́CVे type. This study also reveals that the Low tone on the second syllabic peak of a V́CV sequence is realized physically as a High-falling tone. In other words, $\mathrm{F}_{0}$ variation on the second syllabic peak has its source in the frequency zone of the preceding High tone. Acoustic results presented in Table 4 in APPENDIX II clearly show that the onset of this tone is realized as a level tone (in the same frequency zone as the preceding High tone) for the first $20 \mathrm{~ms}$ or more before the usual down glide (in the case of words with intervocalic voiced consonants). Where the intervocalic consonant is voiceless, the $\mathrm{F}_{0} \mathrm{i}$ value of the second syllabic peak is usually higher than the $\mathrm{F}_{0} f$ of the first syllabic peak. In cases where the $\mathrm{F}_{0} \mathrm{i}$ of the second syllabic peak is lower than the $\mathrm{F}_{0} \mathrm{f}$ of the first syllabic peak by $3 / 4$ of a tone or more, i.e. where the $\mathrm{F}_{0} \mathrm{i}$ of the second syllabic peak is not in the same freqency zone as the $F_{0} f$ of the first syllabic peak, there is distortion of the usual Low tone perception in such V́CV words, i.e. a High-falling tone (cf. the word [ázà] pronounced by $\mathrm{FR}_{3}$ and [íbà] pronounced by $\mathrm{CH}_{2}$ ). The Low tone in such cases is perceived more or less like the low tone of a V́CVे word of the neighbouring and closely related Esan language, i.e. as a Low level tone. This study therefore corroborates earlier claims (based essentially on structural/auditory analyses) in respect of the realization of a Low tone after a High tone in Edo, viz. there is an assimilatory tonal process whereby a Low tone following a High tone is first assimilated to the level of the preceding High before its characteristic downglide (cf. Amayo [1976]; Omozuwa [1987a]). This phenomenon has been described by Hyman [1973, 1975] for other languages. Thus a $\mathrm{H}-\mathrm{L}$ sequence is realized as a $\mathrm{H}-\mathrm{HL}$. 


\section{Comments on Acceptability/Unacceptability of Pronunciation to the Native Speakers/Hearers}

In this section we shall make some brief remarks on the acceptability/unacceptability judgements of the non-Edo speakers' repetitions of the test words by the ten Edo speakers/hearers. We will equally comment on the influence of the mother tongue (and some other factors) of the non-Edo speakers on the amount of "mistakes" made in producing Edo tones.

2.1. V́CV words. The repetitions of five out of the eight non-Edo speakers were accepted as being properly pronounced. The repetitions of the word [úko] 'gourd' by $\mathrm{FR}_{2}$ and $\mathrm{FR}_{3}$ were rejected by all the "judges". It could be observed from the acoustic tracings that the direction of change of $\mathrm{F}_{0}$ realization of the High tone on the first syllabic peak is completely different from that of the accepted tokens: $F_{0} f$ of $V_{1}$ is less than its $F_{0} i$ whereas $F_{0} f$ of $V_{2}$ is more than its $F_{0} i$ in the case of $F_{2}$; $\mathrm{F}_{0} \mathrm{f}$ of $\mathrm{V}_{2}$ is equal to its $\mathrm{F}_{0} \mathrm{i}$ in the case of $\mathrm{FR}_{3}$. Consequently, the "word" [ùkó] (which is meaningless in Edo) is perceived instead of the stimulus [úko] presented. The same explanation holds for the repetition of the word [úku] 'praise name for Edo king' by $\mathrm{FR}_{3}$ and perceived by Edo listeners as [ùku'] which is also meaningless. In this case, even though $\mathrm{F}_{0} f$ of $\mathrm{V}_{1}$ is equal to its $\mathrm{F}_{0} \mathrm{i}$, its $\mathrm{F}_{0} 2 / 3$ is different from $\mathrm{F}_{0} \mathrm{i}$ and $\mathrm{F}_{0} \mathrm{f}$ by $3 / 4$ of a musical tone, i.e. $12 \mathrm{~Hz}$ (according to the conversion scale used in this work since $F_{0}$ values were taken in quarters of tone below a reference frequency of $600 \mathrm{~Hz}$ ). On the other hand, $F_{0}$ of $V_{2}$ is more than $F_{0} f$ of $V_{1}$ by one musical tone. This was what probably gave the perceptual impression of a Low tone on the first syllabic peak contrasting with a High tone on the second syllabic peak (cf. §1.2.2 above).

The repetitions of the seven V́CV́ words by the HS speaker were judged to be "partially accepted", "accepted from a non-native speaker", etc., by the ten Edo listeners. A close observation of the $F_{0}$ contour of these test words as realized by the HS speaker reveals that the duration of the first syllabic peak is highly exaggerated. Moreover, $\mathrm{F}_{0} \mathrm{i}$ to $\mathrm{F}_{0} 2 / 3$ is considerably lower in pitch than $\mathrm{F}_{0} \mathrm{f}$. Thus a "Rising tone" is perceived (cf. Omozuwa [1987a:307]) on $V_{1}$ rendering the pronunciation an "unnatural" realization of the V́CV́ stimulus. However, a difference in meaning was not signalled by the Edo native speaker/hearers since there is no distinctive $\mathrm{R}$ - H tonal melody on VCV words.

2.2. V $\mathbf{V} \grave{V}$ words. Some of the repetitions of four out of the eight non-Edo speakers were judged "unnatural" or "partially accepted" or "accepted from a non-native" by the ten Edo listeners. The repetition of the word [idi] by $\mathrm{CH}_{2}$ was considered "partially accepted" even though the Low-Low tone melody on the VCV word 
was "properly" realized. This partial acceptability arises from the fact that the $\mathrm{CH}_{2}$ speaker used the voiced alveolar fricative $[z]$ instead of the voiced alveolar stop $[d]$ in intervocalic position of the word, i.e. [ìdì] was realized as [izĩ ]. The words [üdè] and $[\grave{o} k \grave{o}]$ pronounced by $\mathrm{FR}_{2}$ and $\mathrm{FR}_{3}$ were considered "partially accepted by Edo native speakers" in view of the fact that the direction of change of the $\mathrm{F}_{0}$ realization on $V_{1}$ is different from that of $V_{2}: F_{0} f$ of $V_{1}$ is more than its $F_{0} i$ whereas $F_{0} f$ of $V_{2}$ is less than its $F_{0} i$. Consequently, a High tone is perceived on $V_{1}$ whereas a

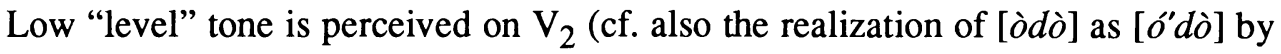
$\mathrm{FR}_{3}$ ). If the low tone on $\mathrm{V}_{2}$ were realized by this speaker as a Falling tone, i.e. the usual realization of a Low tone after a High tone in Edo (cf. §2.4), the way [òdò] was realized by $\mathrm{FR}_{3}$ would have led to a difference in meaning since the Edo language contrasts /òdò/ 'yellow fever' with /ódò/ [ódô] 'potash'. However, [óddò] as realized by $\mathrm{FR}_{3}$ was considered as a foreigner's pronunciation of /ódò/ 'potash', i.e. a tonetic "level" Low tone after a High as in the neighbouring and closely related Esan language instead of a tonetic Falling tone after a High in Edo. As characteristic of HS's repetition, the words /ùdè/, /ùdù/, /òdò/, and /àdà/ were realized as

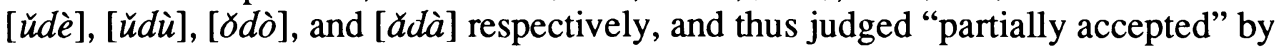
the Edo listeners. This is remarkably different from the way the same HS speaker realized the words [ùgò] 'name of a village' and [òkò] 'parcel'. The pronunciation of these words by HS was unanimously accepted by the Edo listeners.

2.3. V̀CV́ words. Some of the repetitions of six out of the eight non-Edo speakers were either "rejected" or considered "partially accepted" by the ten Edo listeners.

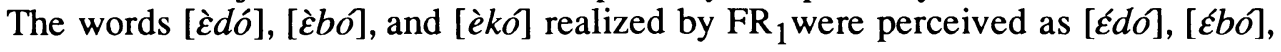
and [ékó] respectively. They were thus rejected by the Edo listeners since they have no meaning. The $F_{0}$ realization of the first two words by $F_{1}$ reveals that $F_{0} f$ of the first syllabic peak is more than its $\mathrm{F}_{0} \mathrm{i}\left(\mathrm{F}_{0} \mathrm{i}\right.$ to $\mathrm{F}_{0} 2 / 3$ of the second syllabic peak being the same as the $\mathrm{F}_{0} \mathrm{f}$ of the first syllabic peak). In the case of the word [èko] realized by $\mathrm{FR}_{1}$ and perceived by the Edo listeners as [éko], it would be observed tha the $\mathrm{F}_{0}$ variation is nil on both the first and second syllables: $252 \mathrm{~Hz}$ (corresponding to 30 quarters of a musical tone on our conversion scale) from the beginning to the end of the $\mathrm{F}_{0}$ realization on the first syllabic peak, $260 \mathrm{~Hz}$ (corresponding to 29 quarters of a musical tone) from the beginning to the end of the $\mathrm{F}_{0}$ realization on the second syllabic peak. Thus the difference between the pitch of the first syllabic peak and that of the second syllabic peak is $4 \mathrm{~Hz}$ corresponding to $1 / 4$ of a musical tone below $600 \mathrm{~Hz}$ ). This seems to suggest that a $1 / 4$ of a musical tone is not sufficient to distinguish a Low tone from a High tone in Edo V̇CV́ words. This corroborates our earlier claim that for a V̌ V́ tone sequence to be perceived in Edo, the difference between the $\mathrm{F}_{0} \mathrm{f}$ of $\mathrm{V}_{1}$ and the $\mathrm{F}_{0} \mathrm{i}$ of $\mathrm{V}_{2}$ must 
be more than $1 / 4$ of a musical tone. A difference of $1 / 4$ of a musical tone (or less) between the $F_{0} f$ of $V_{1}$ and the $F_{0} i$ of $V_{2}$ renders such a VCV́ tone pattern to be perceived as a V́CV́ pattern as shown by the pronunciation of the word [èkó] by $\mathrm{FR}_{1}$ (cf. also the $\mathrm{F}_{0}$ contour of the same word realized by the HS speaker, rejected as the V̀CV́ stimulus, and perceived as a V́CV́ "word" with no specific meaning in Edo). The pronunciatoin of the word [ $\left[\dot{\varepsilon} d o\right.$ ] by $\mathrm{FR}_{2}$ was considered partially accepted by the Edo native speakers/hearers in view of the fact that this speaker realized the V̀CV́ pattern as a VCV̌ pattern, a tone pattern that does not exist in Edo. Similarly, the pronunciation of the words [ $\left[\dot{b} b o ́\right.$ ], [àkó], and [ùdó] by $\mathrm{FR}_{2}$ was considered partially accepted because the direction of change of the $F_{0}$ realization on the first syllabic peak is the same as that of the second syllabic peak, i.e. $F_{0} f$ is $>$ $\mathrm{F}_{0} \mathrm{i}$ in each syllabic peak in most cases, and $\mathrm{F}_{0} f$ of $\mathrm{V}_{1}$ is the same or very close to the $\mathrm{F}_{0} \mathrm{i}$ of $\mathrm{V}_{2}$. This is probably what gave the perceptual impression of a V́CV́ tone sequence, thus rendering the words pronounced "unnatural" in the ears of the native listeners.

2.4. V́CV̀ words. As noted earlier, for a pitch contour to be an acceptable realization of a / $V \overline{C V} /$ word in Edo, i.e. tonetically [V́CV] , the $\mathrm{F}_{0} \mathrm{i}$ of $\mathrm{V}_{2}$ should, ideally, be equal to or more than the $F_{0} f$ of $V_{1}$ but not less than it by more than $3 / 4$ of a musical tone.

The non-Edo speakers' repetition of this tone pattern was generally better than that of the other tone patterns recorded since they made fewer "mistakes" in its production. All the repetitions of three out of the eight non-Edo speakers were considered acceptable pronunciations of the stimuli presented. The repetition of the word /íbà/ by $\mathrm{CH}_{2}$, the word lázà/ by $\mathrm{HS}$ and $\mathrm{FR}_{3}$, and the word /ákò/ by $\mathrm{HS}$ were considered "partially accepted" by the native speakers/hearers. A close observation of the $\mathrm{F}_{0}$ realization of these tokens pronounced by the non-Edo speakers reveals that the $F_{0}$ contour of the Low tone on the second syllabic peak is "not properly realized" the way it should be in Edo, i.e. $F_{0} i$ of $V_{2}$ should be in the same perceptual range as the $\mathrm{F}_{0}$ f of $\mathrm{V}_{1}$.

Let us consider the word /íbàl for instance. In the speech of the Edo native speaker recorded, $F_{0} i$ of $V_{2}$ is less than $F_{0} f$ of $V_{1}$ by $1 / 4$ of a musical tone. This is also true of the repetitions of the same word by IK and $F_{2}$ speakers. $F_{0} i$ of $V_{2}$ is equal to $\mathrm{F}_{0} \mathrm{f}$ of $\mathrm{V}_{1}$ in the repetitions of $\mathrm{YB}, \mathrm{FR}_{1}$, and $\mathrm{CH}_{1}$ speakers for the same word. The difference between the $F_{0} i$ of $V_{2}$ and the $F_{0} f$ of $V_{1}$ is $1 / 2$ of a musical tone in the repetition of the $\mathrm{FR}_{3}$ speaker, and this was accepted by the native speakers/hearers. In the case of the repetition of the same word by the HS speaker, this value is one musical tone. Six out of the ten native listeners rejected this pronunciation whereas the remaining four responded that the pronunciation was par- 
tially acceptable "at least from a non-native speaker". Similarly the repetition of the word /ákò/ by the HS speaker was partially accepted by the native listeners even though "the pronunciation sounds unnatural". It could be noted from the $F_{0}$ realization of this word by HS that the tone on the first syllabic peak was realized as a Rising tone. The result is that /ákò/ is perceived as [ăkò]. However, the difference between the $F_{0} f$ of $V_{1}$ and the $F_{0} i$ of $V_{2}$ for this word pronounced by this speaker (HS) is $1 / 4$ of a musical tone, i.e. $F_{0} i$ of $V_{2}$ is more than the $F_{0} f$ of $V_{1}$ by a quarter of a musical tone. Thus, this may not have been responsible for its partial acceptability. Compare the $\mathrm{F}_{0}$ realization of the word /ázàa by this same speaker. This was also partially accepted by the native listeners. In this word, the High tone on the first syllabic peak was not only realized as a Rising tone but also the difference between the $F_{0} i$ of $V_{2}$ and the $F_{0} f$ of $V_{1}$ is five quarters of a tone.

Finally, five out of the ten native speakers/hearers were undecided on whether the pronunciation of the words /ákò/ by $\mathrm{FR}_{2}$ and /údè/ by $\mathrm{FR}_{2}$ and $\mathrm{CH}_{2}$ were fully acceptable or partially acceptable whereas the remaining five listeners felt that the repetitions were partially acceptable. The difference between the $F_{0} i$ of $V_{2}$ and the $\mathrm{F}_{0} \mathrm{f}$ of $\mathrm{V}_{1}$ is one musical tone (cf. the realization of /íbà/ by the HS speaker as analysed above). It might be that one musical tone difference between the $\mathrm{F}_{0} \mathrm{i}$ of $V_{2}$ and the $F_{0} f$ of $V_{1}$ serves as the perceptual threshold for the perception of a $/ \mathrm{VCV} /$ tone pattern in Edo, i.e. if $\mathrm{F}_{0} \mathrm{i}$ of $\mathrm{V}_{2}$ is less than $\mathrm{F}_{0} f$ of $\mathrm{V}_{1}$. The perception of this tone pattern is distorted if this value is more than a musical tone. Words with such a /V́CV்/ tone pattern will therefore sound "unnatural" or like the pronunciation of similar words in the neighbouring Esan language. Synthesized materials would be required in order to be able to manipulate the various variables highlighted in this study with a view to determining the acoustic cue(s) and the perceptual threshhold for the perception of the four tone patterns in Edo disyllabic nouns.

\section{Conclusion}

This study which is based on acoustic and perceptual analyses reveals that certain acoustic cues are indispensable for an Edo speaker/hearer in the perception of tones of disylabic nouns:

(a) The acoustic cue for the perception of a sequence of High tones on a V́CV́ word is the upward movement of $\mathrm{F}_{0}$ in the same frequency zone intra syllabic or inter syllabic. These tones can also be realized as level tones in such words, i.e. $F_{0}$ variation from the beginning to the end of the $F_{0}$ realization is nil. 
(b) In a sequence of Low tones the acoustic cue is a decrease in $F_{0}$ values from the beginning to the end of the $\mathrm{F}_{0}$ realization on each of the syllabic peaks even though in some cases the $F_{0}$ values are the same from the beginning to the end of the $\mathrm{F}_{0}$ realization on the first syllabic peak. A Low tone is perceived globally from the beginning of the first syllabic peak to the end of the second syllabic peak in both cases.

(c) The $\mathrm{F}_{0}$ difference which must not be less than $1 / 4$ of a musical tone between the end point of the $\mathrm{F}_{0}$ realization of the Low tone on the first syllabic peak and the High tone on the second syllabic peak in a V́VV sequence is the major acoustic cue for the perception of these contrastive tones in such sequence.

(d) In a V́CV sequence, the Low tone on the second syllabic peak is realized as a High-falling tone since it has its origin from the frequency zone of the preceding High tone, a case of tonal assimilation.

Results of this investigation show that the form and direction of change of $\mathrm{F}_{0}$ variation are the most important acoustic cues for the perception of tones in Edo. This can be realized in different ways depending on the tone pattern as well as the frequency zone characteristic of each of the two tonemes (cf. similar perceptual studies in Yoruba by Hombert [1976], Dojio [1978]).

This investigation equally reveals that a phonologically Low tone is realized differently in physical terms depending on its position in a word, i.e. whether or not it is preceding or following a High tone and/or whether or not it is following another Low tone.

It can be inferred from results of this study that the mother tongue of a listener influences his/her perception/repetition of the tone melody of the words of a given tone language: the more closely related the languages are, the higher the performance of such non-native listeners. Moreover, a trained phonetician and/or musicologist (whose language is non-tonal) who is used to manipulating musical pitch differences is likely to have a greater ability in the perception/repetition of pitch variations in a tone language than his counterpart who has not received such training.

It would appear from results of this study that the ears of a native speaker accommodate a wide range of pitch variations in his acceptability/non-acceptability of a given tone melody produced by a non-native speaker, especially if the word bearing such a tone melody is not in minimal contrast with another word having a different tone melody.

More investigations need to be carried out to verify these claims, especially in the areas of speech synthesis and automatic recognition of speech. 


\section{APPENDIX I}

EDO V́CV́WORDS
Words
Phonetic Realization Gloss
1. úkó
[úkó]
2. ágó
[ágó]
'gourd'
3. úkú
[úku]
4. úgú
[úgú]
5. ádá
[áda]
6. íbá
[íbá]
7. ágá
[ágá]
'can'
'praise name for Edo king'
'name of a clan'
'sceptre'
'mischief'
'chair'

EDO $\grave{V} C \grave{V}$ WORDS
Words
Phonetic Realiza
[ùgò $]$
[ìdì]
2. idin
[idi]
3. àdà
[àdà]
4. òkò
[òkò]
5. ùdù
[ùdù]
6. ùdè
[ùdè]
Gloss
7. òdò
[òdò]
'name of a village'
'grave'
'crossroad'
'parcel'
'heart'
'advice'
'yellow fever'

EDO $\grave{V} C V ́$ WORDS

Words Phonetic Realization Gloss
1. èdó
[غेdo]
2. èbó
[cेbo]
'Edo (language)'
3. èkó
[èkó]
4. àkó
[àkó]
5. òkó
[òko]
'charm'
6. ùgó
[ùgó]
'Lagos'
'portion'
'nest'
7. ùdó
[ùdó]
'a plant'
'name of a village' 


\section{EDO V́CV̀ WORDS}

\begin{tabular}{|c|c|c|}
\hline Words & Phonetic Realization & Gloss \\
\hline 1. íbà & [íbà] & 'mud bed' \\
\hline 2. ókò & [ókò] & 'a flute' \\
\hline 3. údè & [údè] & 'spleen ailment' \\
\hline 4. ázà & [ázà] & 'treasury' \\
\hline 5. ókà & [ك́kà] & 'maize' \\
\hline 6. ákò & [ákò] & 'a fruit' \\
\hline 7. ébò & [ébò] & 'white man' \\
\hline
\end{tabular}

\section{APPENDIX II}

\section{Tables of Results}

Table 1a: $F_{0}$ and duration values for seven Edo V́CV́ words pronounced by a female Edo speaker

\begin{tabular}{|c|c|c|c|c|c|c|c|c|c|c|c|}
\hline \multirow{2}{*}{$\begin{array}{l}\text { SER. } \\
\text { No. }\end{array}$} & \multirow[t]{2}{*}{ WORDS } & \multicolumn{3}{|c|}{ FIRST SYLLABLE } & \multirow[b]{2}{*}{$\mathrm{F}_{0} \mathrm{~m}$} & \multirow{2}{*}{\begin{tabular}{|l} 
DURA \\
-TION \\
\end{tabular}} & \multicolumn{3}{|c|}{ SECOND SYLABLE } & \multirow[b]{2}{*}{$\mathrm{F}_{0} \mathrm{~m}$} & \multirow{2}{*}{\begin{tabular}{|l} 
DURA \\
-TION \\
\end{tabular}} \\
\hline & & $\mathrm{F}_{0^{\mathrm{i}}}$ & $\mathrm{F}_{0} 2 / 3$ & $F_{0} f$ & & & $\overline{F_{0}} \dot{ }$ & $\mathrm{F}_{0} 2 / 3$ & $\mathrm{~F}_{0} \mathrm{f}$ & & \\
\hline 1. & {$[u ́ k \sigma]^{1}$} & 252 & 252 & 252 & 252 & 80 & 252 & 252 & 252 & 252 & 150 \\
\hline 2. & [ágo] & 260 & 260 & 260 & 260 & 120 & 260 & 260 & 260 & 260 & 210 \\
\hline 3. & [úku] & 275 & 275 & 275 & 275 & 120 & 275 & 275 & 275 & 275 & 160 \\
\hline 4. & [úgü] & 245 & 260 & 260 & 255 & 100 & 260 & 260 & 260 & 260 & 120 \\
\hline 5. & [áda] & 212 & 238 & 238 & 229 & 150 & 238 & 238 & 238 & 238 & 190 \\
\hline 6. & [íbá] & 245 & 252 & 252 & 250 & 120 & 245 & 245 & 245 & 245 & 220 \\
\hline 7. & [ágá] & 252 & 260 & 260 & 257 & 130 & 260 & 275 & 275 & 270 & 170 \\
\hline
\end{tabular}

${ }^{1} \mathrm{~F}_{0} \mathrm{i}$ for the first syllabic peak for the words [ádá] and [íbá] as realized by ED were $212 \mathrm{~Hz}$ and $245 \mathrm{~Hz}$ respectively for the first $40 \mathrm{~ms}$, after which it rose to $238 \mathrm{~Hz}$ and $252 \mathrm{~Hz}$ respectively for each of the two words. $\mathrm{FR}_{1}$ also realized $\mathrm{F}_{0} \mathrm{i}$ of the first syllabic peak of the word [iba] as $225 \mathrm{~Hz}$ for $40 \mathrm{~ms}$ before it rose to $252 \mathrm{~Hz}$. For the same syllabic peak and for the same word, $F_{0}$ value for $\mathrm{HS}$ was $178 \mathrm{~Hz}$ realized for $70 \mathrm{~ms}$ before it rose to $200 \mathrm{~Hz}$. It is probably as a result of the nature of $\mathrm{F}_{0}$ realization on this syllabic peak that the High tone was perceived as a Rising tone thereby resulting in its unacceptabilty by the Edo native speakers/hearers. 
Table 1b: $\mathrm{F}_{0}$ and duration values for seven Edo V́CV́ words pronounced by eight non-Edo speakers in a listening task ${ }^{2}$

\begin{tabular}{|c|c|c|c|c|c|c|c|c|c|c|c|c|}
\hline \multirow{2}{*}{$\begin{array}{l}\text { SER. } \\
\text { NO. } \\
\end{array}$} & \multirow[t]{2}{*}{ WORDS } & \multirow{2}{*}{$\begin{array}{l}\text { SPEAK- } \\
\text { ERS } \\
\end{array}$} & \multicolumn{3}{|c|}{ FIRST SYLLABLE } & \multirow[b]{2}{*}{$\mathrm{F}_{0} \mathrm{~m}$} & \multirow{2}{*}{\begin{tabular}{|l} 
DURA \\
-TION \\
\end{tabular}} & \multicolumn{3}{|c|}{ SECOND SYLABLE } & \multirow{2}{*}{$\overline{\mathrm{F}_{0} \mathrm{~m}}$} & \multirow{2}{*}{\begin{tabular}{|l} 
DURA \\
-TION \\
\end{tabular}} \\
\hline & & & $\overline{F_{0}}$ & $\overline{F_{0} 2 / 3}$ & $\overline{F_{0} f}$ & & & $\mathrm{~F}_{0} \mathrm{i}$ & $\mathrm{F}_{0} 2 / 3$ & $\overline{F_{0} f}$ & & \\
\hline 1. & [úko] & $\overline{Y B}$ & 130 & 126 & 123 & 126 & 120 & 130 & 130 & 130 & 130 & 140 \\
\hline & & IK & 126 & 138 & 142 & 135 & 110 & 146 & 146 & 150 & 147 & 170 \\
\hline & * & HS & 178 & 200 & 200 & 193 & 80 & 200 & 200 & 200 & 200 & 200 \\
\hline & & $\mathrm{FR}_{1}$ & 252 & 275 & 275 & 267 & 60 & 275 & 275 & 275 & 275 & 110 \\
\hline & $* *$ & $\mathrm{FR}_{2}$ & 225 & 200 & 189 & 205 & 90 & 245 & 245 & 275 & 255 & 200 \\
\hline & $* *$ & $\mathrm{FR}_{3}$ & 146 & 146 & 126 & 139 & 80 & 159 & 159 & 159 & 159 & 80 \\
\hline & & $\mathrm{CH}_{1}$ & 126 & 126 & 126 & 126 & 140 & 130 & 134 & 134 & 133 & 170 \\
\hline & & $\mathrm{CH}_{2}$ & 189 & 195 & 200 & 195 & 120 & 195 & 195 & 195 & 195 & 150 \\
\hline
\end{tabular}

\begin{tabular}{|c|c|c|c|c|c|c|c|c|c|c|c|c|}
\hline \multirow{2}{*}{$\begin{array}{l}\text { SER. } \\
\text { No. }\end{array}$} & \multirow[t]{2}{*}{ | WORDS } & \multirow[t]{2}{*}{\begin{tabular}{|l} 
SPEAK- \\
ERS \\
\end{tabular}} & \multicolumn{3}{|c|}{ FIRST SYLLABLE } & \multirow[b]{2}{*}{$\mathrm{F}_{0} \mathrm{~m}$} & \multirow[t]{2}{*}{\begin{tabular}{|l} 
DURA \\
-TION \\
\end{tabular}} & \multicolumn{3}{|c|}{ SECOND SYLABLE } & \multirow[b]{2}{*}{$\mathrm{F}_{0} \mathrm{~m}$} & \multirow[t]{2}{*}{\begin{tabular}{|l} 
DURA \\
-TION \\
\end{tabular}} \\
\hline & & & $\overline{\mathrm{F}_{0} \mathrm{i}}$ & $\mathrm{F}_{0} 2 / 3$ & $\mathrm{~F}_{0} \mathrm{f}$ & & & $\mathrm{F}_{0} \mathrm{i}$ & $\mathrm{F}_{0} 2 / 3$ & $\overline{F_{0} f}$ & & \\
\hline$\overline{2}$. & [ágó] & $\overline{\mathrm{YB}}$ & 123 & 126 & 126 & 125 & 120 & 126 & 126 & 126 & 126 & 160 \\
\hline & & IK & 112 & 126 & 130 & 123 & 110 & 123 & 138 & 142 & 134 & 150 \\
\hline & * & HS & 146 & 184 & 200 & 17 & 170 & 200 & 212 & 21 & 20 & 240 \\
\hline & & $\mathrm{FR}_{1}$ & 252 & 252 & 252 & 252 & 160 & 252 & 252 & 245 & 250 & 150 \\
\hline & & $\mathrm{FR}_{2}$ & 206 & 225 & 231 & 221 & 70 & 252 & 252 & 252 & 252 & 220 \\
\hline & & $\mathrm{FR}_{3}$ & 142 & 146 & 150 & 146 & 60 & 146 & 154 & 159 & 153 & 130 \\
\hline & & $\mathrm{CH}_{1}$ & 134 & 134 & 134 & 134 & 130 & 138 & 138 & 138 & 138 & 160 \\
\hline & & $\mathrm{CH}_{2}$ & 164 & 168 & 168 & 167 & 180 & 164 & 168 & 184 & 172 & 200 \\
\hline
\end{tabular}

\begin{tabular}{|c|c|c|c|c|c|c|c|c|c|c|c|c|}
\hline \multirow{2}{*}{$\begin{array}{l}\text { SER. } \\
\text { No. }\end{array}$} & \multirow[t]{2}{*}{ WORDS } & \multirow{2}{*}{\begin{tabular}{|l} 
SPEAK- \\
ERS \\
\end{tabular}} & \multicolumn{3}{|c|}{ FIRST SYLLABLE } & \multirow[b]{2}{*}{$\overline{F_{0} \mathrm{~m}}$} & \multirow{2}{*}{$\begin{array}{l}\text { DURA } \\
\text {-TION } \\
\end{array}$} & \multicolumn{3}{|c|}{ SECOND SYLABLE } & \multirow[b]{2}{*}{$\overline{\mathrm{F}_{0} \mathrm{~m}}$} & \multirow{2}{*}{$\begin{array}{l}\text { DURA } \\
\text {-TION } \\
\end{array}$} \\
\hline & & & $\bar{F}_{0}$ & $\mathrm{~F}_{0} 2 / 3$ & $\overline{F_{0} f}$ & & & $\mathrm{~F}_{0^{\mathrm{i}}}$ & $\mathrm{F}_{0} 2 / 3$ & $\mathrm{~F}_{0} \mathrm{f}$ & & \\
\hline \multirow[t]{8}{*}{3.} & [úkú] & YB & 138 & 138 & 138 & 138 & 140 & 138 & 138 & 138 & 138 & 160 \\
\hline & & IK & 134 & 146 & 146 & 142 & 130 & 138 & 142 & 150 & 143 & 160 \\
\hline & * & $\mathrm{HS}$ & 206 & 225 & 231 & 221 & 130 & 231 & 231 & 231 & 231 & 190 \\
\hline & & $\mathrm{FR}_{1}$ & 252 & 260 & 267 & 260 & 140 & 275 & 275 & 275 & 275 & 150 \\
\hline & * & $\mathrm{FR}_{2}$ & 231 & 275 & 300 & 269 & 100 & 300 & 300 & 300 & 300 & 150 \\
\hline & $* *$ & $\mathrm{FR}_{3}$ & 142 & 154 & 142 & 146 & 110 & 159 & 178 & 178 & 172 & 120 \\
\hline & & $\mathrm{CH}_{1}$ & 146 & 146 & 146 & 146 & 100 & 146 & 146 & 146 & 146 & 160 \\
\hline & & $\mathrm{CH}_{2}$ & 189 & 195 & 200 & 195 & 160 & 195 & 195 & 195 & 195 & 220 \\
\hline
\end{tabular}

${ }^{2}$ The following symbols were used for the acceptability judgement:

* $\quad$ (for partially accepted tokens)

** (for rejected tokens)

? (for borderline cases) 


\begin{tabular}{|c|c|c|c|c|c|c|c|c|c|c|c|c|}
\hline \multirow{2}{*}{$\begin{array}{l}\text { SER. } \\
\text { No. } \\
\end{array}$} & \multirow[t]{2}{*}{ WORDS } & \multirow{2}{*}{$\begin{array}{l}\text { SPEAK- } \\
\text { ERS }\end{array}$} & \multicolumn{3}{|c|}{ FIRST SYLLABLE } & \multirow[b]{2}{*}{$\mathrm{F}_{0} \mathrm{~m}$} & \multirow{2}{*}{$\begin{array}{l}\text { DURA } \\
\text {-TION } \\
\end{array}$} & \multicolumn{3}{|c|}{ SECOND SYLABLE } & \multirow[b]{2}{*}{$\mathrm{F}_{0} \mathrm{~m}$} & \multirow{2}{*}{$\begin{array}{l}\text { DURA } \\
\text {-TION } \\
\end{array}$} \\
\hline & & & $\mathrm{F}_{0^{\mathrm{i}}}$ & $\mathrm{F}_{0} 2 / 3$ & $\mathrm{~F}_{0} \mathrm{f}$ & & & $\bar{F}_{0}{ }^{i}$ & $\mathrm{~F}_{0} 2 / 3$ & $\bar{F}_{0} f$ & & \\
\hline 4. & [úgu & YB & 130 & 130 & 130 & 130 & 140 & 126 & 126 & 126 & 126 & 120 \\
\hline & & IK & 134 & 142 & 142 & 139 & 80 & 138 & 146 & 150 & 145 & 130 \\
\hline & * & $\mathrm{HS}$ & 173 & 206 & 212 & 197 & 180 & 212 & 212 & 212 & 212 & 180 \\
\hline & & $\mathrm{FR}_{1}$ & 252 & 252 & 252 & 252 & 110 & 260 & 260 & 260 & 260 & 100 \\
\hline & & $\mathrm{FR}_{2}$ & 212 & 231 & 252 & 232 & 100 & 275 & 275 & 283 & 278 & 90 \\
\hline & & $\mathrm{FR}_{3}$ & 146 & 154 & 154 & 151 & 80 & 146 & 159 & 164 & 156 & 100 \\
\hline & & $\mathrm{CH}_{1}$ & 134 & 134 & 134 & 134 & 120 & 138 & 138 & 134 & 137 & 150 \\
\hline & & $\mathrm{CH}_{2}$ & 189 & 195 & 200 & 195 & 150 & 195 & 195 & 195 & 195 & 160 \\
\hline
\end{tabular}

\begin{tabular}{|c|c|c|c|c|c|c|c|c|c|c|c|c|}
\hline \multirow{2}{*}{$\begin{array}{l}\text { SER. } \\
\text { No. }\end{array}$} & \multirow[t]{2}{*}{ WORDS } & \multirow{2}{*}{\begin{tabular}{|l} 
SPEAK- \\
ERS
\end{tabular}} & \multicolumn{3}{|c|}{ FIRST SYLLABLE } & \multirow[b]{2}{*}{$\mathrm{F}_{0} \mathrm{~m}$} & \multirow{2}{*}{\begin{tabular}{|l} 
DURA \\
-TION \\
\end{tabular}} & \multicolumn{3}{|c|}{ SECOND SYLABLE } & \multirow[b]{2}{*}{$\mathrm{F}_{0} \mathrm{~m}$} & \multirow{2}{*}{$\begin{array}{l}\text { DURA } \\
\text {-TION } \\
\end{array}$} \\
\hline & & & $\overline{F_{0} \mathrm{i}}$ & $\mathrm{F}_{0} 2 / 3$ & $\mathrm{~F}_{0} \mathrm{f}$ & & & $\mathrm{F}_{0} \mathrm{i}$ & $\mathrm{F}_{0} 2 / 3$ & $\mathrm{~F}_{0} \mathrm{f}$ & & \\
\hline \multirow[t]{8}{*}{5.} & [ádá] & YB & 123 & 123 & 123 & 123 & 160 & 123 & 123 & 123 & 123 & 220 \\
\hline & & IK & 126 & 126 & 126 & 126 & 160 & 12 & 126 & 150 & 13 & 130 \\
\hline & * & HS & 123 & 154 & 159 & 145 & 160 & 159 & 159 & 159 & 159 & 240 \\
\hline & & $\mathrm{FR}_{1}$ & 245 & 245 & 245 & 245 & 150 & 245 & 245 & 245 & 245 & 150 \\
\hline & & $\mathrm{FR}_{2}$ & 225 & 231 & 252 & 236 & 160 & 245 & 245 & 245 & 245 & 190 \\
\hline & & $\mathrm{FR}_{3}$ & 142 & 142 & 142 & 142 & 110 & 142 & 142 & 146 & 143 & 100 \\
\hline & $?$ & $\mathrm{CH}_{1}$ & 130 & 123 & 123 & 125 & 120 & 123 & 123 & 126 & 124 & 170 \\
\hline & & & 164 & 173 & 173 & 170 & 180 & 173 & 178 & 178 & 176 & 180 \\
\hline
\end{tabular}

\begin{tabular}{|c|c|c|c|c|c|c|c|c|c|c|c|c|}
\hline \multirow{2}{*}{$\begin{array}{l}\text { SER } \\
\text { No. } \\
\end{array}$} & \multirow[t]{2}{*}{ WORDS } & \multirow{2}{*}{$\begin{array}{l}\text { SPEAK- } \\
\text { ERS } \\
\end{array}$} & \multicolumn{3}{|c|}{ FIRST SYLLABLE } & \multirow[b]{2}{*}{$\mathrm{F}_{0} \mathrm{~m}$} & \multirow{2}{*}{\begin{tabular}{|l} 
DURA \\
-TION \\
\end{tabular}} & \multicolumn{3}{|c|}{ SECOND SYLABLE } & \multirow[b]{2}{*}{$\mathrm{F}_{0} \mathrm{~m}$} & \multirow{2}{*}{\begin{tabular}{|l} 
DURA \\
-TION \\
\end{tabular}} \\
\hline & & & $\overline{F_{0}}{ }^{i}$ & $\mathrm{~F}_{0} 2 / 3$ & $\overline{F_{0} f}$ & & & $\overline{F_{0} \mathrm{i}}$ & $\mathrm{F}_{0} 2 / 3$ & $F_{0} f$ & & \\
\hline \multirow{8}{*}{6.} & [íbá] & $\overline{Y B}$ & 126 & 126 & 126 & 126 & 90 & 123 & 123 & 123 & 123 & 160 \\
\hline & & IK & 126 & 142 & 142 & 137 & 150 & 126 & 134 & 142 & 134 & 150 \\
\hline & * & HS & 178 & 200 & 200 & 193 & 160 & 200 & 200 & 200 & 200 & 180 \\
\hline & & $\mathrm{FR}_{1}$ & 225 & 252 & 252 & 243 & 180 & 252 & 252 & 252 & 252 & 170 \\
\hline & & $\mathrm{FR}_{2}$ & 238 & 245 & 252 & 245 & 90 & 245 & 245 & 252 & 247 & 200 \\
\hline & & $\mathrm{FR}_{3}$ & 134 & 138 & 142 & 138 & 80 & 142 & 146 & 150 & 146 & 110 \\
\hline & & $\mathrm{CH}_{1}$ & 134 & 134 & 134 & 134 & 80 & 134 & 134 & 134 & 134 & 160 \\
\hline & & $\mathrm{CH}_{2}$ & 173 & 195 & 195 & 188 & 180 & 195 & 195 & 178 & 189 & 170 \\
\hline
\end{tabular}

\begin{tabular}{|c|c|c|c|c|c|c|c|c|c|c|c|c|}
\hline \multirow{2}{*}{$\begin{array}{l}\text { SER } \\
\text { No. }\end{array}$} & \multirow[t]{2}{*}{ WORDS } & \multirow{2}{*}{$\begin{array}{l}\text { SPEAK- } \\
\text { ERS } \\
\end{array}$} & \multicolumn{3}{|c|}{ FIRST SYLLABLE } & \multirow[b]{2}{*}{$\mathrm{F}_{0} \mathrm{~m}$} & \multirow{2}{*}{$\begin{array}{l}\text { DURA } \\
\text {-TION } \\
\end{array}$} & \multicolumn{3}{|c|}{ SECOND SYLABLE } & & \multirow{2}{*}{$\begin{array}{l}\text { DURA } \\
\text {-TION } \\
\end{array}$} \\
\hline & & & $\overline{F_{0}} \mathrm{i}$ & $\mathrm{F}_{0} 2 / 3$ & $\overline{F_{0} f}$ & & & $\mathrm{~F}_{0} \mathrm{i}$ & $\overline{\mathrm{F}_{0} 2 / 3}$ & $\overline{F_{0} f}$ & $\mathrm{~F}_{0} \mathrm{~m}$ & \\
\hline 7. & [ágá] & YB & 126 & 126 & 126 & 126 & 160 & 126 & 126 & 126 & 126 & 190 \\
\hline & & IK & 123 & 126 & 138 & 129 & 140 & 126 & 126 & 142 & 131 & 190 \\
\hline & * & HS & 159 & 184 & 195 & 179 & 160 & 195 & 195 & 195 & 195 & 210 \\
\hline & & $\mathrm{FR}_{1}$ & 267 & 260 & 252 & 260 & 200 & 252 & 252 & 252 & 252 & 160 \\
\hline & & $\mathrm{FR}_{2}$ & 206 & 225 & 260 & 230 & 160 & 275 & 245 & 252 & 257 & 190 \\
\hline & & $\mathrm{CH}_{1}$ & 126 & 126 & 126 & 126 & 120 & 126 & 126 & 123 & 125 & 200 \\
\hline & & $\mathrm{CH}_{2}$ & 164 & 168 & 173 & 168 & 240 & 178 & 178 & 178 & 178 & 80 \\
\hline
\end{tabular}


Table 2a: $F_{0}$ and duration values for seven Edo V̀CV̀ words pronounced by a female Edo speaker

\begin{tabular}{|c|c|c|c|c|c|c|c|c|c|c|c|}
\hline \multirow[t]{2}{*}{ SER. } & \multirow[t]{2}{*}{ WORDS } & \multicolumn{3}{|c|}{ FIRST SYLLABLE } & \multirow[b]{2}{*}{$\mathrm{F}_{0} \mathrm{~m}$} & \multirow{2}{*}{$\begin{array}{l}\text { DURA } \\
\text {-TION } \\
\end{array}$} & \multicolumn{3}{|c|}{ SECOND SYLABLE } & \multicolumn{2}{|r|}{\begin{tabular}{|l} 
DURA \\
-TION
\end{tabular}} \\
\hline & & $F_{0^{i}}$ & $\mathrm{~F}_{0} 2 / 3$ & $F_{0} f$ & & & $F_{0^{i}}$ & $\mathrm{~F}_{0} 2 / 3$ & $\mathrm{~F}_{0} \mathrm{f}$ & $\mathrm{F}_{0} \mathrm{~m}$ & \\
\hline$\because 0$ & {$[\grave{u}$} & 0 & 238 & $\overline{23}$ & 233 & 80 & 231 & 189 & 14 & 18 & \\
\hline 2. & & & & & & & & & & & \\
\hline & & & & & & & & & & & \\
\hline & & & 2 & & & 8 & & & & & \\
\hline 5 & {$[\grave{a}$} & 212 & 2 & 20 & 2 & 13 & & & & 17 & \\
\hline 6. & {$[\partial k$} & & & & & & & & & & \\
\hline 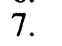 & {$[\grave{o d o ̀]}$} & 231 & 212 & 206 & 216 & 160 & 206 & 178 & 159 & 181 & 160 \\
\hline
\end{tabular}

Table 2b: $\mathrm{F}_{0}$ and duration values for seven Edo V̀CV̀ words pronounced by eight non-Edo speakers in a listening task

\begin{tabular}{|c|c|c|c|c|c|c|c|c|c|c|c|c|}
\hline \multirow[t]{2}{*}{ SER. } & \multirow[t]{2}{*}{ WORDS } & \multirow{2}{*}{$\begin{array}{l}\text { SPEAK } \\
\text { ERS } \\
\end{array}$} & \multicolumn{3}{|c|}{ FIRST SYLLABLE } & & \multirow{2}{*}{$\begin{array}{l}\text { DURA } \\
\text {-TRON } \\
\end{array}$} & \multicolumn{3}{|c|}{ SECOND SYLABLE } & \multicolumn{2}{|r|}{$\mid \begin{array}{l}\text { DURA } \\
\text {-TION }\end{array}$} \\
\hline & & & $\mathrm{F}_{0} \mathrm{i}$ & $\mathrm{F}_{0} 2 / 3$ & $\mathrm{~F}_{0} \mathrm{f}$ & $\mathrm{F}_{0} \mathrm{~m}$ & & $F_{0}{ }^{i}$ & $\mathrm{~F}_{0} 2 / 3$ & $F_{0} f$ & $\mathrm{~F}_{0} \mathrm{~m}$ & \\
\hline 1. & {$[\grave{u} g \grave{o}]$} & YB & 119 & 119 & 119 & 119 & 90 & 112 & 103 & 89 & 101 & 130 \\
\hline & & & 134 & 13 & 119 & 129 & 120 & 116 & & 94 & & \\
\hline & & HS & 18 & 18 & 195 & 191 & 140 & 17 & & 103 & & \\
\hline & & $\mathrm{FR}_{1}$ & 231 & 231 & 231 & 231 & 80 & 225 & 200 & 178 & 201 & 130 \\
\hline & * & $\mathrm{FR}_{2}$ & 212 & 23 & 252 & 23 & 80 & 195 & 146 & 138 & 160 & 150 \\
\hline & * & $\mathrm{FR}_{3}$ & 138 & 159 & 164 & 154 & 80 & 154 & & 109 & 134 & 80 \\
\hline & & $\mathrm{CH}_{1}$ & 138 & 134 & 134 & 135 & 120 & 130 & 10 & 97 & 110 & 110 \\
\hline & & $\mathrm{CH}$ & 195 & 189 & 184 & 189 & 120 & 164 & 159 & 126 & 150 & 90 \\
\hline
\end{tabular}

\begin{tabular}{|c|c|c|c|c|c|c|c|c|c|c|c|c|}
\hline \multirow[t]{2}{*}{$\begin{array}{l}\text { SER. } \\
\text { No. }\end{array}$} & \multirow[t]{2}{*}{ | WORDS } & \multirow{2}{*}{\begin{tabular}{|l} 
SPEAK- \\
ERS \\
\end{tabular}} & \multicolumn{3}{|c|}{ FIRST SYLLABLE } & & \multirow{2}{*}{$\begin{array}{l}\text { DURA } \\
\text {-TION } \\
\end{array}$} & \multicolumn{3}{|c|}{ SECOND SYLABLE } & \multirow[b]{2}{*}{$\overline{\mathrm{F}_{0} \mathrm{~m}}$} & \multirow{2}{*}{$\begin{array}{l}\text { DURA } \\
\text {-TION } \\
\end{array}$} \\
\hline & & & $F_{0} i$ & $\mathrm{~F}_{0} 2 / 3$ & $\mathrm{~F}_{0} \mathrm{f}$ & $\mathrm{F}_{0} \mathrm{~m}$ & & $F_{0}{ }^{i}$ & $\mathrm{~F}_{0^{2 / 3}}$ & $\mathrm{~F}_{0} \mathrm{f}$ & & \\
\hline 2 . & {$[\bar{i} d \hat{i}]$} & $\mathrm{YB}$ & 126 & 126 & 116 & 123 & 90 & 116 & 103 & 100 & 106 & 180 \\
\hline & & $W$ & & & & & 130 & & & & & \\
\hline & * & $\mathrm{HS}$ & 14 & 206 & 212 & 18 & 130 & 18 & 106 & 97 & 131 & 260 \\
\hline & & FR & 267 & 260 & 260 & 26 & 120 & 21 & 184 & 159 & 185 & 160 \\
\hline & * & $\mathrm{FR}_{2}$ & 20 & 22 & 212 & 22 & 80 & 173 & 146 & 134 & 151 & 120 \\
\hline & * & $\mathrm{FR}_{3}$ & 134 & 154 & 154 & 147 & 60 & 150 & 154 & 130 & 145 & 90 \\
\hline & & $\mathrm{CH}_{1}$ & 138 & 138 & 134 & 137 & 120 & 12 & 10 & 97 & 108 & 90 \\
\hline & & & 178 & 195 & 164 & 179 & 120 & 164 & 138 & 126 & 143 & 0 \\
\hline
\end{tabular}




\begin{tabular}{|c|c|c|c|c|c|c|c|c|c|c|c|c|}
\hline \multirow{2}{*}{$\begin{array}{l}\text { SER. } \\
\text { No. }\end{array}$} & \multirow[t]{2}{*}{ WORDS } & \multirow{2}{*}{$\begin{array}{l}\text { SPEAK- } \\
\text { ERS } \\
\end{array}$} & \multicolumn{3}{|c|}{ FIRST SYLLABLE } & \multirow[b]{2}{*}{$\mathrm{F}_{0} \mathrm{~m}$} & \multirow{2}{*}{\begin{tabular}{|l} 
DURA \\
-TTON \\
\end{tabular}} & \multicolumn{3}{|c|}{ SECOND SYLABLE } & \multirow[b]{2}{*}{$\mathrm{F}_{0} \mathrm{~m}$} & \multirow{2}{*}{$\begin{array}{l}\text { DURA } \\
\text {-TION } \\
\end{array}$} \\
\hline & & & $\overline{F_{0}}$ & $\overline{F_{0} 2 / 3}$ & $F_{0} f$ & & & $\overline{F_{0}}{ }^{i}$ & $\mathrm{~F}_{0} 2 / 3$ & $\mathrm{~F}_{0} f$ & & \\
\hline 3. & {$[\grave{u} d \grave{u}]$} & $\overline{Y B}$ & 138 & 130 & 126 & 131 & 140 & 126 & 116 & 97 & 113 & 140 \\
\hline & & IK & 138 & 138 & 134 & 137 & 160 & 126 & 116 & 89 & 110 & 190 \\
\hline & * & HS & 189 & 206 & 218 & 204 & 160 & 178 & 119 & 103 & 133 & 280 \\
\hline & & $\mathrm{FR}_{1}$ & 245 & 245 & 238 & 243 & 120 & 231 & 200 & 173 & 201 & 180 \\
\hline & * & $\mathrm{FR}_{2}$ & 231 & 238 & 238 & 236 & 140 & 206 & 168 & 138 & 171 & 190 \\
\hline & * & $\mathrm{FR}_{3}$ & 138 & 150 & 164 & 151 & 100 & 159 & 159 & 154 & 157 & 90 \\
\hline & & $\mathrm{CH}_{1}$ & 150 & 146 & 138 & 145 & 160 & 138 & 123 & 106 & 122 & 160 \\
\hline & * & $\mathrm{CH}_{2}$ & 178 & 195 & 195 & 189 & 200 & 195 & 150 & 126 & 157 & 180 \\
\hline
\end{tabular}

\begin{tabular}{|c|c|c|c|c|c|c|c|c|c|c|c|c|}
\hline \multirow{2}{*}{$\begin{array}{l}\text { SER. } \\
\text { No. }\end{array}$} & \multirow[t]{2}{*}{ WORDS } & \multirow{2}{*}{\begin{tabular}{|l} 
SPEAK- \\
ERS \\
\end{tabular}} & \multicolumn{3}{|c|}{ FIRST SYLLABLE } & \multirow[b]{2}{*}{$\mathrm{F}_{0} \mathrm{~m}$} & \multirow{2}{*}{\begin{tabular}{|l} 
DURA \\
-TION \\
\end{tabular}} & \multicolumn{3}{|c|}{ SECOND SYLABLE } & \multirow[b]{2}{*}{$\mathrm{F}_{0} \mathrm{~m}$} & \multirow{2}{*}{$\begin{array}{l}\text { DURA } \\
\text {-TION } \\
\end{array}$} \\
\hline & & & $\overline{F_{0}}{ }^{i}$ & $\mathrm{~F}_{0} 2 / 3$ & $\overline{F_{0} f}$ & & & $\mathrm{~F}_{0} \mathrm{i}$ & $\mathrm{F}_{0} 2 / 3$ & $\overline{F_{0} f}$ & & \\
\hline 4. & 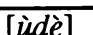 & $\overline{Y B}$ & 126 & 123 & 119 & 123 & 90 & 116 & 109 & 97 & 107 & 150 \\
\hline & & IK & 126 & 126 & 126 & 126 & 80 & 12 & 116 & 94 & 111 & 170 \\
\hline & * & HS & 173 & 206 & 212 & 197 & 150 & 189 & 126 & 94 & 136 & 270 \\
\hline & & $\mathrm{FR}_{1}$ & 252 & 252 & 252 & 252 & 130 & 225 & 178 & 164 & 189 & 200 \\
\hline & & $\mathrm{FR}_{2}$ & 225 & 231 & 231 & 229 & 80 & 195 & 159 & 134 & 163 & 140 \\
\hline & & $\mathrm{FR}_{3}$ & 150 & 150 & 150 & 150 & 80 & 146 & 126 & 97 & 123 & 170 \\
\hline & & $\mathrm{CH}_{1}$ & 138 & 142 & 126 & 135 & 150 & 126 & 119 & 106 & 117 & 150 \\
\hline & & $\mathrm{CF}$ & 212 & 206 & 173 & 197 & 170 & 164 & 146 & 138 & 149 & 80 \\
\hline
\end{tabular}

\begin{tabular}{|c|c|c|c|c|c|c|c|c|c|c|c|c|}
\hline \multirow{2}{*}{$\begin{array}{l}\text { SER } \\
\text { No. }\end{array}$} & \multirow[t]{2}{*}{ WORDS } & \multirow{2}{*}{$\begin{array}{l}\text { SPEAK- } \\
\text { ERS } \\
\end{array}$} & \multicolumn{3}{|c|}{ FIRST SYLLABLE } & \multirow[b]{2}{*}{$\mathrm{F}_{0} \mathrm{~m}$} & \multirow{2}{*}{$\begin{array}{l}\text { DURA } \\
\text {-TION } \\
\end{array}$} & \multicolumn{3}{|c|}{ SECOND SYLABLE } & \multirow[b]{2}{*}{$\mathrm{F}_{0} \mathrm{~m}$} & \multirow{2}{*}{\begin{tabular}{|l} 
DURA \\
-TION \\
\end{tabular}} \\
\hline & & & $\overline{F_{0} i}$ & $\mathrm{~F}_{0} 2 / 3$ & $\overline{F_{0} f}$ & & & $\overline{F_{0}}$ & $\mathrm{~F}_{0} 2 / 3$ & $\mathrm{~F}_{0} \mathrm{f}$ & & \\
\hline \multirow[t]{8}{*}{5.} & [àdà] & YB & 106 & 106 & 103 & 105 & 130 & 109 & 97 & 92 & 99 & 130 \\
\hline & & IK & 123 & 119 & 116 & 119 & 160 & 106 & 94 & 89 & 96 & 180 \\
\hline & * & HS & 116 & 134 & 138 & 129 & 140 & 138 & 106 & 97 & 114 & 240 \\
\hline & & $\mathrm{FR}_{1}$ & 212 & 212 & 212 & 212 & 120 & 195 & 184 & 150 & 176 & 160 \\
\hline & & $\mathrm{FR}_{2}$ & 195 & 195 & 195 & 195 & 80 & 195 & 134 & 116 & 148 & 190 \\
\hline & & $\mathrm{FR}_{3}$ & 150 & 150 & 150 & 150 & 80 & 146 & 123 & 94 & 121 & 150 \\
\hline & & $\mathrm{CH}_{1}$ & 126 & 130 & 126 & 127 & 110 & 126 & 106 & 97 & 110 & 150 \\
\hline & & $\mathrm{CH}_{2}$ & 164 & 164 & 164 & 164 & 200 & 159 & 134 & 116 & 136 & 160 \\
\hline
\end{tabular}

\begin{tabular}{|c|c|c|c|c|c|c|c|c|c|c|c|c|}
\hline \multirow{2}{*}{$\begin{array}{l}\text { SER } \\
\text { No. } \\
\end{array}$} & \multirow[t]{2}{*}{ WORDS } & \multirow{2}{*}{$\begin{array}{l}\text { SPEAK- } \\
\text { ERS } \\
\end{array}$} & \multicolumn{3}{|c|}{ FIRST SYLLABLE } & \multirow[b]{2}{*}{$\mathrm{F}_{0} \mathrm{~m}$} & \multirow{2}{*}{$\begin{array}{l}\text { DURA } \\
\text {-TION } \\
\end{array}$} & \multicolumn{3}{|c|}{ SECOND SYLABLE } & \multirow[b]{2}{*}{$\overline{\mathrm{F}_{0} \mathrm{~m}}$} & \multirow{2}{*}{$\begin{array}{l}\text { DURA } \\
\text {-TION } \\
\end{array}$} \\
\hline & & & $\bar{F}_{0} \dot{ }$ & $\mathrm{F}_{0} 2 / 3$ & $\overline{F_{0} f}$ & & & $\mathrm{~F}_{0^{i}}$ & $\mathrm{~F}_{0} 2 / 3$ & $\overline{F_{0} f}$ & & \\
\hline 6. & {$[\grave{\partial k} \partial]$} & YB & 116 & 116 & 109 & 114 & 110 & 116 & 112 & 100 & 109 & 90 \\
\hline & & IK & 12 & 123 & 116 & 12 & 140 & 126 & 103 & 89 & 106 & 150 \\
\hline & & $\mathrm{HS}$ & 178 & 178 & 178 & 178 & 160 & 178 & 138 & 106 & 141 & 290 \\
\hline & & $\mathrm{FR}_{1}$ & 231 & 231 & 231 & 231 & 120 & 231 & 189 & 159 & 193 & 200 \\
\hline & * & $\mathrm{FR}_{\text {? }}$ & 195 & 231 & 252 & 226 & 100 & 231 & 150 & 138 & 173 & 170 \\
\hline & * & $\mathrm{FR}_{3}$ & 150 & 159 & 164 & 158 & 80 & 138 & 123 & 97 & 119 & 160 \\
\hline & & $\mathrm{CH}_{1}$ & 134 & 126 & 126 & 129 & 120 & 126 & 103 & 97 & 109 & 120 \\
\hline & & $\mathrm{CH}_{2}$ & 178 & 164 & 138 & 160 & 230 & 159 & 134 & 119 & 137 & 150 \\
\hline
\end{tabular}




\begin{tabular}{|c|c|c|c|c|c|c|c|c|c|c|c|c|}
\hline $\begin{array}{l}\text { SER } \\
\text { No. }\end{array}$ & \multirow[t]{2}{*}{ WORDS } & \multirow{2}{*}{\begin{tabular}{|l} 
SPEAK- \\
ERS
\end{tabular}} & \multicolumn{3}{|c|}{ | FIRST SYLLABLE } & \multirow[b]{2}{*}{$\mathrm{F}_{0} \mathrm{~m}$} & \multirow{2}{*}{\begin{tabular}{|l} 
DURA \\
-TION \\
\end{tabular}} & \multicolumn{3}{|c|}{ SECOND SYLABLE } & \multirow[b]{2}{*}{$\mathrm{F}_{0} \mathrm{~m}$} & \multirow{2}{*}{$\begin{array}{l}\text { DURA } \\
\text {-TION } \\
\end{array}$} \\
\hline & & & $\overline{F_{0}}{ }^{i}$ & $\mathrm{~F}_{0} 2 / 3$ & $\mathrm{~F}_{0} \mathrm{f}$ & & & $\mathrm{F}_{0} \mathrm{i}$ & $\mathrm{F}_{0} 2 / 3$ & $\mathrm{~F}_{0} f$ & & \\
\hline \multirow[t]{8}{*}{7.} & {$[\grave{\partial d \partial]}$} & YB & 116 & 112 & 106 & 111 & 160 & 109 & 103 & 94 & 102 & 120 \\
\hline & & IK & 119 & 116 & 116 & 117 & 160 & 112 & 97 & 82 & 97 & 140 \\
\hline & & HS & 138 & 142 & 142 & 141 & 120 & 138 & 119 & 97 & 118 & 280 \\
\hline & & $\mathrm{FR}_{1}$ & 218 & 212 & 212 & 214 & 160 & 212 & 178 & 159 & 183 & 220 \\
\hline & & $\mathrm{FR}_{2}$ & 212 & 212 & 212 & 212 & 140 & 189 & 134 & 112 & 145 & 160 \\
\hline & * & $\mathrm{FR}_{3}$ & 142 & 150 & 154 & 149 & 100 & 138 & 119 & 97 & 118 & 120 \\
\hline & & $\mathrm{CH}_{1}$ & 138 & 138 & 126 & 134 & 130 & 126 & 116 & 103 & 115 & 130 \\
\hline & & $\mathrm{CH}_{2}$ & 164 & 168 & 164 & 165 & 170 & 159 & 134 & 123 & 139 & 100 \\
\hline
\end{tabular}

Table 3a: $\quad F_{0}$ and duration values for seven Edo V̀CV́ words pronounced by a female Edo speaker

\begin{tabular}{|c|c|c|c|c|c|c|c|c|c|c|c|}
\hline \multirow{2}{*}{$\begin{array}{l}\text { SER. } \\
\text { NO. }\end{array}$} & \multirow[t]{2}{*}{ WORDS } & \multicolumn{3}{|c|}{ | FIRST SYLLABLE } & \multirow[b]{2}{*}{$\mathrm{F}_{0} \mathrm{~m}$} & \multirow{2}{*}{\begin{tabular}{|l} 
DURA \\
-TION \\
\end{tabular}} & \multicolumn{3}{|c|}{ SECOND SYLABLE } & \multirow[b]{2}{*}{$\mathrm{F}_{0} \mathrm{~m}$} & \multirow{2}{*}{\begin{tabular}{|l|} 
DURA \\
-TION \\
\end{tabular}} \\
\hline & & $\mathrm{F}_{0^{\mathrm{i}}}^{\mathrm{i}}$ & $\mathrm{F}_{0} 2 / 3$ & $\overline{F_{0} f}$ & & & $\overline{F_{0}}{ }^{i}$ & $F_{0} 2 / 3$ & $\mathrm{~F}_{0} \mathrm{f}$ & & \\
\hline 1. & {$[\dot{\varepsilon} d \sigma]$} & 218 & 218 & 218 & 218 & 110 & 231 & 231 & 231 & 231 & 180 \\
\hline 2. & {$[\dot{\varepsilon} b \sigma]$} & 212 & 212 & 212 & 212 & 100 & 231 & 231 & 231 & 231 & 190 \\
\hline 3. & [èko] & 231 & 231 & 231 & 231 & 80 & 267 & 267 & 267 & 267 & 200 \\
\hline 4. & [àko] & 218 & 218 & 218 & 218 & 80 & 245 & 245 & 245 & 245 & 120 \\
\hline 5. & [oko] & 218 & 218 & 218 & 218 & 90 & 238 & 238 & 231 & 236 & 190 \\
\hline 6. & [uेgo] & 23 & 231 & 231 & 231 & 100 & 252 & 252 & 252 & 252 & 200 \\
\hline 7. & [uेdo] & 231 & 231 & 231 & 231 & 130 & 252 & 252 & 252 & 252 & 240 \\
\hline
\end{tabular}

Table 3b: $\mathrm{F}_{0}$ and duration values for seven Edo V̀CV́ words pronounced by eight non-Edo speakers in a listening task

\begin{tabular}{|c|c|c|c|c|c|c|c|c|c|c|c|c|}
\hline \multirow{2}{*}{$\begin{array}{l}\text { SER. } \\
\text { No. }\end{array}$} & \multirow[t]{2}{*}{ WORDS } & \multirow{2}{*}{$\begin{array}{l}\text { SPEAK- } \\
\text { ERS }\end{array}$} & \multicolumn{3}{|c|}{ | FIRST SYLLABLE } & \multirow[b]{2}{*}{$\mathrm{F}_{0} \mathrm{~m}$} & \multirow{2}{*}{\begin{tabular}{|l} 
DURA \\
-TION \\
\end{tabular}} & \multicolumn{3}{|c|}{ SECOND SYLABLE } & \multirow[b]{2}{*}{$\mathrm{F}_{0} \mathrm{~m}$} & \multirow{2}{*}{\begin{tabular}{|l} 
DURA \\
-TION \\
\end{tabular}} \\
\hline & & & $\mathrm{F}_{0^{\mathrm{i}}}^{\mathrm{i}}$ & $\mathrm{F}_{0} 2 / 3$ & $F_{0} f$ & & & $\overline{F_{0}}{ }^{i}$ & $\mathrm{~F}_{0} 2 / 3$ & $\overline{F_{0} f}$ & & \\
\hline 1. & {$[\overline{\varepsilon d \sigma]}$} & YB & 109 & 109 & 109 & 109 & 140 & 126 & 126 & 126 & 126 & 160 \\
\hline & & IK & 119 & 119 & 119 & 119 & 90 & 126 & 138 & 142 & 135 & 130 \\
\hline & * & HS & 138 & 150 & 150 & 146 & 140 & 164 & 164 & 164 & 164 & 240 \\
\hline & ** & $\mathrm{FR}_{1}$ & 225 & 231 & 231 & 229 & 150 & 231 & 231 & 225 & 229 & 120 \\
\hline & $*$ & $\mathrm{FR}_{2}$ & 206 & 206 & 206 & 206 & 120 & 218 & 245 & 275 & 246 & 210 \\
\hline & * & $\mathrm{FR}_{3}$ & 138 & 138 & 142 & 139 & 80 & 142 & 154 & 142 & 146 & 110 \\
\hline & * & $\mathrm{CH}_{1}$ & 134 & 138 & 138 & 137 & 120 & 138 & 138 & 138 & 138 & 120 \\
\hline & * & $\mathrm{CH}_{2}$ & 150 & 164 & 164 & 159 & 120 & 168 & 168 & 168 & 168 & 160 \\
\hline
\end{tabular}




\begin{tabular}{|c|c|c|c|c|c|c|c|c|c|c|c|c|}
\hline \multirow{2}{*}{$\begin{array}{l}\text { SER. } \\
\text { No. }\end{array}$} & \multirow[t]{2}{*}{ WORDS } & \multirow{2}{*}{\begin{tabular}{|l} 
SPEAK- \\
ERS \\
\end{tabular}} & \multicolumn{3}{|c|}{ FIRST SYLLABLE } & \multirow[b]{2}{*}{$\mathrm{F}_{0} \mathrm{~m}$} & \multirow{2}{*}{$\begin{array}{l}\text { DURA } \\
\text {-TION }\end{array}$} & \multicolumn{3}{|c|}{ SECOND SYLABLE } & \multirow[b]{2}{*}{$\mathrm{F}_{0} \mathrm{~m}$} & \multirow{2}{*}{$\begin{array}{l}\text { DURA } \\
\text {-TION }\end{array}$} \\
\hline & & & $\mathrm{F}_{0} \mathrm{i}$ & $F_{0} 2 / 3$ & $F_{0} f$ & & & $\mathrm{~F}_{0} \mathrm{i}$ & $\mathrm{F}_{0} 2 / 3$ & $F_{0} f$ & & \\
\hline 2. & [غेbó] & YB & 116 & 116 & 116 & 116 & 80 & 126 & 126 & 126 & 126 & 120 \\
\hline & & IK & 116 & 116 & 116 & 116 & 130 & 123 & 138 & 150 & 137 & 140 \\
\hline & * & $\mathrm{HS}$ & 173 & 184 & 184 & 180 & 200 & 200 & 212 & 245 & 219 & 200 \\
\hline & $* *$ & $\mathrm{FR}_{1}$ & 231 & 231 & 231 & 231 & 160 & 231 & 231 & 231 & 231 & 200 \\
\hline & $* *$ & $\mathrm{FR}_{2}$ & 206 & 225 & 238 & 223 & 120 & 238 & 260 & 245 & 248 & 210 \\
\hline & & $\mathrm{FR}_{3}$ & 138 & 138 & 134 & 137 & 60 & 134 & 150 & 150 & 145 & 100 \\
\hline & & $\mathrm{CH}_{1}$ & 123 & 119 & 116 & 119 & 120 & 130 & 130 & 126 & 129 & 160 \\
\hline & & $\mathrm{CH}_{2}$ & 159 & 164 & 164 & 162 & 220 & 178 & 195 & 195 & 189 & 180 \\
\hline
\end{tabular}

\begin{tabular}{|c|c|c|c|c|c|c|c|c|c|c|c|c|}
\hline \multirow{2}{*}{$\begin{array}{l}\text { SER. } \\
\text { No. } \\
\end{array}$} & \multirow[t]{2}{*}{ WORDS } & \multirow{2}{*}{\begin{tabular}{|l} 
SPEAK- \\
ERS \\
\end{tabular}} & \multicolumn{3}{|c|}{ FIRST SYLLABLE } & \multirow[b]{2}{*}{$\mathrm{F}_{0} \mathrm{~m}$} & \multirow{2}{*}{$\begin{array}{l}\text { DURA } \\
\text {-TION } \\
\end{array}$} & \multicolumn{3}{|c|}{ SECOND SYLABLE } & \multirow[b]{2}{*}{$\mathrm{F}_{0} \mathrm{~m}$} & \multirow{2}{*}{$\begin{array}{l}\text { DURA } \\
\text {-TION } \\
\end{array}$} \\
\hline & & & $\mathrm{F}_{0} \mathrm{i}$ & $\mathrm{F}_{0} 2 / 3$ & $\overline{F_{0} f}$ & & & $\overline{F_{0}}$ & $\mathrm{~F}_{0} 2 / 3$ & $\overline{F_{0} f}$ & & \\
\hline 3. & [èkó] & YB & 126 & 126 & 126 & 126 & 110 & 138 & 138 & 138 & 138 & 160 \\
\hline & & IK & 12 & 126 & 126 & 126 & 120 & 138 & 138 & 164 & 147 & 140 \\
\hline & $* * *$ & HS & 173 & 173 & 173 & 173 & 160 & 178 & 178 & 178 & 178 & 220 \\
\hline & $* *$ & $\mathrm{FR}_{1}$ & 252 & 252 & 252 & 252 & 130 & 260 & 260 & 260 & 260 & 140 \\
\hline & $* *$ & $\mathrm{FR}_{2}$ & 206 & 225 & 238 & 223 & 100 & 238 & 275 & 252 & 255 & 170 \\
\hline & & $\mathrm{FR}_{3}$ & 154 & 154 & 154 & 154 & 70 & 154 & 173 & 173 & 167 & 100 \\
\hline & & $\mathrm{CH}_{1}$ & 112 & 112 & 112 & 112 & 80 & 134 & 134 & 134 & 134 & 160 \\
\hline & & $\mathrm{CF}$ & 150 & 168 & 164 & 161 & 80 & 195 & 195 & 195 & 195 & 190 \\
\hline
\end{tabular}

\begin{tabular}{|c|c|c|c|c|c|c|c|c|c|c|c|c|}
\hline \multirow{2}{*}{$\begin{array}{l}\text { SER } \\
\text { No. } \\
\end{array}$} & \multirow[t]{2}{*}{ WORDS } & \multirow{2}{*}{$\begin{array}{l}\text { SPEAK- } \\
\text { ERS } \\
\end{array}$} & \multicolumn{3}{|c|}{ FIRST SYLLABLE } & \multirow[b]{2}{*}{$\mathrm{F}_{0} \mathrm{~m}$} & \multirow{2}{*}{$\begin{array}{l}\text { DURA } \\
\text {-TION }\end{array}$} & \multicolumn{3}{|c|}{ | SECOND SYLABLE } & \multirow[b]{2}{*}{$\mathrm{F}_{0} \mathrm{~m}$} & \multirow{2}{*}{\begin{tabular}{|l} 
DURA \\
-TION \\
\end{tabular}} \\
\hline & & & $\overline{F_{0}}$ & $\mathrm{~F}_{0} 2 / 3$ & $\overline{F_{0} f}$ & & & $\overline{F_{0}}{ }^{i}$ & $\mathrm{~F}_{0} 2 / 3$ & $\mathrm{~F}_{0} f$ & & \\
\hline 4. & [àkó] & YB & 112 & 112 & 116 & 113 & 90 & 126 & 126 & 123 & 125 & 120 \\
\hline & & IK & 106 & 106 & 119 & 110 & 150 & 126 & 13 & 126 & 127 & 170 \\
\hline & ** & HS & 142 & 178 & 189 & 170 & 200 & 206 & 20 & 206 & 206 & 220 \\
\hline & & $\mathrm{FR}_{1}$ & 225 & 225 & 218 & 223 & 140 & 27 & 252 & 245 & 257 & 190 \\
\hline & ** & $\mathrm{FR}_{2}$ & 200 & 225 & 231 & 219 & 90 & 238 & 267 & 267 & 257 & 170 \\
\hline & & $\mathrm{FR}_{3}$ & 138 & 138 & 138 & 138 & 50 & 138 & 154 & 159 & 150 & 120 \\
\hline & & $\mathrm{CH}_{1}$ & 119 & 119 & 119 & 119 & 120 & 123 & 130 & 123 & 125 & 120 \\
\hline & & $\mathrm{CH}_{2}$ & 154 & 154 & 154 & 154 & 130 & 173 & 178 & 184 & 178 & 170 \\
\hline
\end{tabular}

\begin{tabular}{|c|c|c|c|c|c|c|c|c|c|c|c|c|}
\hline \multirow{2}{*}{$\begin{array}{l}\text { SER } \\
\text { No. }\end{array}$} & \multirow[t]{2}{*}{ WORDS } & \multirow{2}{*}{$\begin{array}{l}\text { SPEAK- } \\
\text { ERS }\end{array}$} & \multicolumn{3}{|c|}{ FIRST SYLLABLE } & \multirow[b]{2}{*}{$\overline{\mathrm{F}_{0} \mathrm{~m}}$} & \multirow{2}{*}{$\begin{array}{l}\text { DURA } \\
\text {-TION }\end{array}$} & \multicolumn{3}{|c|}{ SECOND SYLABLE } & & \multirow{2}{*}{$\begin{array}{l}\text { DURA } \\
\text {-TION }\end{array}$} \\
\hline & & & $\mathrm{F}_{0} \mathrm{i}$ & $\overline{F_{0} 2 / 3}$ & $F_{0} f$ & & & $\overline{F_{0}}{ }^{i}$ & $\mathrm{~F}_{0} 2 / 3$ & $\overline{F_{0} f}$ & $\overline{\mathrm{F}_{0} \mathrm{~m}}$ & \\
\hline 5. & {$[\grave{\partial k \sigma}]$} & YB & 116 & 116 & 116 & 116 & 100 & 126 & 126 & 126 & 126 & 160 \\
\hline & & IK & 119 & 119 & 119 & 119 & 140 & 138 & 142 & 142 & 141 & 140 \\
\hline & & HS & 164 & 195 & 200 & 186 & 190 & 225 & 231 & 225 & 227 & 240 \\
\hline & & $\mathrm{FR}_{1}$ & 212 & 231 & 206 & 216 & 130 & 275 & 245 & 245 & 255 & 140 \\
\hline & & $\mathrm{FR}_{2}$ & 173 & 206 & 212 & 197 & 90 & 245 & 2.52 & 245 & 247 & 200 \\
\hline & & $\mathrm{FR}_{3}$ & 138 & 150 & 126 & 138 & 90 & 150 & 168 & 173 & 164 & 100 \\
\hline & & $\mathrm{CH}_{1}$ & 126 & 119 & 112 & 119 & 110 & 134 & 134 & 134 & 134 & 120 \\
\hline & & $\mathrm{CH}_{2}$ & 164 & 164 & 164 & 164 & 150 & 189 & 195 & 195 & 193 & 160 \\
\hline
\end{tabular}




\begin{tabular}{|c|c|c|c|c|c|c|c|c|c|c|c|c|}
\hline \multirow{2}{*}{$\begin{array}{l}\text { SER } \\
\text { No. }\end{array}$} & \multirow[t]{2}{*}{ WORDS } & \multirow{2}{*}{\begin{tabular}{|l} 
SPEAK- \\
ERS
\end{tabular}} & \multicolumn{3}{|c|}{ | FIRST SYLLABLE } & \multirow[b]{2}{*}{$\mathrm{F}_{0} \mathrm{~m}$} & \multirow{2}{*}{$\begin{array}{l}\text { DURA } \\
\text {-TION } \\
\end{array}$} & \multicolumn{3}{|c|}{ SECOND SYLABLE } & \multirow[b]{2}{*}{$\mathrm{F}_{0} \mathrm{~m}$} & \multirow{2}{*}{$\begin{array}{l}\text { DURA } \\
\text {-TION }\end{array}$} \\
\hline & & & $\overline{F_{0}}$ & $\mathrm{~F}_{0} 2 / 3$ & $\overline{F_{0} f}$ & & & $\mathrm{~F}_{0} \mathrm{i}$ & $\mathrm{F}_{0} 2 / 3$ & $F_{0} f$ & & \\
\hline \multirow[t]{8}{*}{6.} & [ùgó] & YB & 116 & 116 & 116 & 116 & 100 & 138 & 138 & 138 & 138 & 140 \\
\hline & & IK & 119 & 119 & 119 & 119 & 120 & 138 & 138 & 142 & 139 & 160 \\
\hline & & HS & 173 & 178 & 178 & 176 & 130 & 206 & 206 & 206 & 206 & 240 \\
\hline & & $\mathrm{FR}_{1}$ & 231 & 231 & 231 & 231 & 110 & 252 & 252 & 245 & 250 & 200 \\
\hline & & $\mathrm{FR}_{2}$ & 206 & 231 & 231 & 223 & 90 & 252 & 252 & 252 & 252 & 280 \\
\hline & $* *$ & $\mathrm{FR}_{3}$ & 138 & 142 & 138 & 139 & 100 & 142 & 150 & 150 & 147 & 120 \\
\hline & & $\mathrm{CH}_{1}$ & 126 & 126 & 126 & 126 & 80 & 138 & 138 & 138 & 138 & 140 \\
\hline & & $\mathrm{CH}_{2}$ & 164 & 164 & 164 & 164 & 160 & 189 & 189 & 189 & 189 & 240 \\
\hline
\end{tabular}

\begin{tabular}{|c|c|c|c|c|c|c|c|c|c|c|c|c|}
\hline \multirow{2}{*}{$\begin{array}{l}\text { SER. } \\
\text { No. }\end{array}$} & \multirow[t]{2}{*}{ WORDS } & \multirow{2}{*}{$\begin{array}{l}\text { SPEAK- } \\
\text { ERS } \\
\end{array}$} & \multicolumn{3}{|c|}{ FIRST SYLLABLE } & \multirow[b]{2}{*}{$\mathrm{F}_{0} \mathrm{~m}$} & \multirow{2}{*}{\begin{tabular}{|l|} 
DURA \\
-TION \\
\end{tabular}} & \multicolumn{3}{|c|}{ SECOND SYLABLE } & \multirow[b]{2}{*}{$\mathrm{F}_{0} \mathrm{~m}$} & \multirow{2}{*}{\begin{tabular}{|l} 
DURA \\
-TION \\
\end{tabular}} \\
\hline & & & $\overline{F_{0}}{ }^{i}$ & $\mathrm{~F}_{0} 2 / 3$ & $F_{0} f$ & & & $\bar{F}_{0} \dot{i}$ & $\mathrm{~F}_{0} 2 / 3$ & $\mathrm{~F}_{0} \mathrm{f}$ & & \\
\hline \multirow{8}{*}{7.} & [йdo] & $\overline{Y B}$ & 119 & 119 & 119 & 119 & 140 & 134 & 134 & 134 & 134 & 200 \\
\hline & & IK & 116 & 116 & 116 & 116 & 120 & 123 & 126 & 142 & 130 & 200 \\
\hline & & HS & 173 & 178 & 178 & 176 & 160 & 189 & 206 & 206 & 200 & 250 \\
\hline & & $\mathrm{FR}_{1}$ & 231 & 231 & 231 & 231 & 140 & 245 & 245 & 245 & 245 & 200 \\
\hline & $* *$ & $\mathrm{FR}_{2}$ & 195 & 225 & 231 & 217 & 90 & 231 & 267 & 275 & 258 & 200 \\
\hline & $* *$ & $\mathrm{FR}_{3}$ & 138 & 138 & 142 & 139 & 70 & 142 & 142 & 146 & 143 & 120 \\
\hline & & $\mathrm{CH}_{1}$ & 116 & 116 & 116 & 116 & 100 & 134 & 134 & 134 & 134 & 160 \\
\hline & & $\mathrm{CH}_{2}$ & 164 & 164 & 164 & 164 & 180 & 189 & 189 & 189 & 189 & 240 \\
\hline
\end{tabular}

Table 4a: $F_{0}$ and duration values for seven Edo V́CV̀ words pronounced by a female Edo speaker

\begin{tabular}{|c|c|c|c|c|c|c|c|c|c|c|c|}
\hline \multirow{2}{*}{$\begin{array}{l}\text { SER. } \\
\text { No. } \\
\end{array}$} & \multirow[t]{2}{*}{ WORDS } & \multicolumn{3}{|c|}{ FIRST SYLLABLE } & \multirow[b]{2}{*}{$\mathrm{F}_{0} \mathrm{~m}$} & \multirow{2}{*}{\begin{tabular}{|l} 
DURA \\
-TION \\
\end{tabular}} & \multicolumn{3}{|c|}{ SECOND SYLABLE } & \multirow[b]{2}{*}{$\mathrm{F}_{0} \mathrm{~m}$} & \multirow{2}{*}{\begin{tabular}{|l} 
DURA \\
-TION \\
\end{tabular}} \\
\hline & & $\mathrm{F}_{0} \mathrm{i}$ & $\mathrm{F}_{0} 2 / 3$ & $F_{0} f$ & & & $\mathrm{~F}_{0^{\mathrm{i}}}$ & $\mathrm{F}_{0} 2 / 3$ & $F_{0} f$ & & \\
\hline 1. & $\overline{[i ́ b \grave{a}]}$ & 267 & 275 & 275 & 272 & 120 & 267 & 195 & 164 & 209 & 160 \\
\hline 2. & {$[\delta k \dot{d}]$} & 245 & 252 & 252 & 250 & 120 & 275 & 212 & 189 & 225 & 120 \\
\hline 3. & [údè] & 275 & 275 & 275 & 275 & 90 & 267 & 225 & 178 & 223 & 150 \\
\hline 4. & [ázà] & 252 & 252 & 252 & 252 & 110 & 252 & 206 & 173 & 210 & 150 \\
\hline 5 & {$[\delta ́ k \grave{a}]$} & 245 & 275 & 275 & 265 & 120 & 275 & 245 & 206 & 242 & 120 \\
\hline 6. & {$[a ́ k d]$} & 245 & 245 & 245 & 245 & 80 & 275 & 225 & 173 & 224 & 100 \\
\hline 7. & {$\left[e^{\prime} b \grave{b}\right]^{3}$} & 267 & 275 & 275 & 272 & 180 & 231 & 206 & 206 & 214 & 150 \\
\hline
\end{tabular}

${ }^{3}$ The low tone on the second syllabic peak of this word is not realized as a Falling tone. It is realized more or less as a level Low tone after a High tone in the neighbouring Esan language; or as a downstepped Low tone. It might be necessary to find out the origin of this word, i.e. whether or not it is a borrowed word. 
Table 4b: $F_{0}$ and duration values for seven Edo V́CV̀ words pronounced by eight non-Edo speakers in a listening task

\begin{tabular}{|c|c|c|c|c|c|c|c|c|c|c|c|c|}
\hline \multirow{2}{*}{$\begin{array}{l}\text { SER } \\
\text { No. }\end{array}$} & \multirow[t]{2}{*}{ WORDS } & \multirow{2}{*}{$\begin{array}{l}\text { SPEAK- } \\
\text { ERS }\end{array}$} & \multicolumn{3}{|c|}{ FIRST SYLLABLE } & \multirow[b]{2}{*}{$\mathrm{F}_{0} \mathrm{~m}$} & \multirow{2}{*}{$\begin{array}{l}\text { DURA } \\
\text {-TION } \\
\end{array}$} & \multicolumn{3}{|c|}{ SECOND SYLABLE } & \multirow[b]{2}{*}{$\mathrm{F}_{0} \mathrm{~m}$} & \multirow{2}{*}{\begin{tabular}{|l} 
DURA \\
-TION \\
\end{tabular}} \\
\hline & & & $\mathrm{F}_{0} \mathrm{i}$ & $\mathrm{F}_{0} 2 / 3$ & $\mathrm{~F}_{0} f$ & & & $\overline{\mathrm{F}_{0} \mathrm{i}}$ & $\mathrm{F}_{0} 2 / 3$ & $\overline{F_{0} f}$ & & \\
\hline \multirow[t]{8}{*}{1.} & [íbà] & $\overline{Y B}$ & 134 & 134 & 134 & 134 & 120 & 134 & 116 & 103 & 118 & 130 \\
\hline & & IK & 138 & 142 & 142 & 141 & 140 & 138 & 112 & 97 & 116 & 150 \\
\hline & * & HS & 164 & 200 & 200 & 188 & 120 & 178 & 138 & 106 & 141 & 140 \\
\hline & & $\mathrm{FR}_{1}$ & 231 & 252 & 260 & 248 & 140 & 260 & 218 & 173 & 217 & 130 \\
\hline & & $\mathrm{FR}_{2}$ & 206 & 245 & 252 & 234 & 120 & 245 & 206 & 173 & 208 & 150 \\
\hline & & $\mathrm{FR}_{3}$ & 146 & 168 & 168 & 161 & 100 & 159 & 126 & 97 & 127 & 190 \\
\hline & & $\mathrm{CH}_{1}$ & 146 & 146 & 146 & 146 & 110 & 146 & 123 & 112 & 127 & 140 \\
\hline & $* *$ & $\mathrm{CH}_{2}$ & 178 & 195 & 195 & 189 & 200 & 164 & 150 & 138 & 151 & 100 \\
\hline
\end{tabular}

\begin{tabular}{|c|c|c|c|c|c|c|c|c|c|c|c|c|}
\hline \multirow{2}{*}{$\begin{array}{l}\text { SER } \\
\text { No. } \\
\end{array}$} & \multirow[t]{2}{*}{ WORDS } & \multirow{2}{*}{$\begin{array}{l}\text { SPEAK- } \\
\text { ERS } \\
\end{array}$} & \multicolumn{3}{|c|}{ FIRST SYLLABLE } & \multirow[b]{2}{*}{$\mathrm{F}_{0} \mathrm{~m}$} & \multirow{2}{*}{\begin{tabular}{|l} 
DURA \\
-TION \\
\end{tabular}} & \multicolumn{3}{|c|}{ SECOND } & \multirow[b]{2}{*}{$\mathrm{F}_{0} \mathrm{~m}$} & \multirow{2}{*}{\begin{tabular}{|l} 
DURA \\
-TION \\
\end{tabular}} \\
\hline & & & $\overline{F_{0}}$ & $\mathrm{~F}_{0} 2 / 3$ & $\overline{F_{0} f}$ & & & $\mathrm{~F}_{0^{\mathrm{i}}}$ & $\mathrm{F}_{0} 2 / 3$ & $\overline{F_{0} f}$ & & \\
\hline 2. & $\left\lceil\sigma_{k}\right.$ & YB & 112 & 116 & 116 & 115 & 100 & 116 & 109 & 103 & 109 & 100 \\
\hline & & IK & 138 & 146 & 164 & 149 & 100 & 138 & 109 & 87 & 111 & 130 \\
\hline & & HS & 154 & 159 & 164 & 159 & 100 & 164 & 119 & 112 & 132 & 180 \\
\hline & & $\mathrm{FR}_{1}$ & 231 & 252 & 231 & 238 & 110 & 252 & 195 & 138 & 195 & 180 \\
\hline & & $\mathrm{FR}_{2}$ & 206 & 267 & 275 & 249 & 120 & 267 & 173 & 146 & 195 & 180 \\
\hline & & $\mathrm{FR}_{3}$ & 159 & 159 & 164 & 161 & 80 & 159 & 134 & 106 & 133 & 160 \\
\hline & & $\mathrm{CH}_{1}$ & 130 & 130 & 130 & 130 & 80 & 126 & 119 & 97 & 114 & 120 \\
\hline & & $\mathrm{CH}_{2}$ & 189 & 195 & 189 & 191 & 120 & 195 & 164 & 126 & 162 & 130 \\
\hline
\end{tabular}

\begin{tabular}{|c|c|c|c|c|c|c|c|c|c|c|c|c|}
\hline \multirow{2}{*}{$\begin{array}{l}\text { SER } \\
\text { No. } \\
\end{array}$} & \multirow[t]{2}{*}{ WORDS } & \multirow{2}{*}{$\begin{array}{l}\text { SPEAK- } \\
\text { ERS } \\
\end{array}$} & \multicolumn{3}{|c|}{ FIRST SYLLABLE } & \multirow[b]{2}{*}{$\mathrm{F}_{0} \mathrm{~m}$} & \multirow{2}{*}{\begin{tabular}{|l} 
DURA \\
-TION \\
\end{tabular}} & \multicolumn{3}{|c|}{ SECOND SYLABLE } & & \multirow{2}{*}{$\begin{array}{l}\text { DURA } \\
\text {-TION } \\
\end{array}$} \\
\hline & & & $\overline{F_{0}}$ & $\mathrm{~F}_{0} 2 / 3$ & $\overline{F_{0} f}$ & & & $\mathrm{~F}_{0^{\mathrm{i}}}$ & $\mathrm{F}_{0} 2 / 3$ & $\overline{F_{0} f}$ & $\mathrm{~F}_{0} \mathrm{~m}$ & \\
\hline \multirow[t]{8}{*}{3.} & [údè] & YB & 138 & 142 & 142 & 141 & 80 & $\overline{142}$ & 123 & 103 & 123 & $\overline{120}$ \\
\hline & & IK & 138 & 154 & 164 & 152 & 90 & 164 & 123 & 97 & 128 & 160 \\
\hline & * & HS & 178 & 231 & 238 & 216 & 130 & 206 & 146 & 112 & 155 & 220 \\
\hline & & $\mathrm{FR}_{1}$ & 231 & 260 & 260 & 250 & 120 & 245 & 189 & 173 & 202 & 170 \\
\hline & $?$ & $\mathrm{FR}_{2}$ & 252 & 267 & 283 & 267 & 110 & 245 & 173 & 134 & 184 & 200 \\
\hline & & $\mathrm{FR}_{3}$ & 150 & 154 & 154 & 153 & 80 & 150 & 112 & 94 & 119 & 180 \\
\hline & & $\mathrm{CH}_{1}$ & 134 & 138 & 138 & 137 & 80 & 138 & 123 & 112 & 124 & 150 \\
\hline & $?$ & $\mathrm{CH}_{2}$ & 195 & 195 & 195 & 195 & 160 & 173 & 159 & 138 & 157 & 110 \\
\hline
\end{tabular}

\begin{tabular}{|c|c|c|c|c|c|c|c|c|c|c|c|c|}
\hline \multirow{2}{*}{$\begin{array}{l}\text { SER. } \\
\text { No. }\end{array}$} & \multirow[t]{2}{*}{ WORDS } & \multirow{2}{*}{$\begin{array}{l}\text { SPEAK- } \\
\text { ERS } \\
\end{array}$} & \multicolumn{3}{|c|}{ FIRST SYLLABLE } & \multirow[b]{2}{*}{$\mathrm{F}_{0} \mathrm{~m}$} & \multirow{2}{*}{\begin{tabular}{|l} 
DURA \\
-TION \\
\end{tabular}} & \multicolumn{3}{|c|}{ SECOND SYLABLE } & \multirow[b]{2}{*}{$\mathrm{F}_{0} \mathrm{~m}$} & \multirow{2}{*}{\begin{tabular}{|l|l|} 
DURA \\
-TION
\end{tabular}} \\
\hline & & & $\overline{F_{0}}$ & $\mathrm{~F}_{0} 2 / 3$ & $\overline{F_{0} f}$ & & & $\mathrm{~F}_{0}{ }^{\mathrm{i}}$ & $\mathrm{F}_{0} 2 / 3$ & $F_{0} f$ & & \\
\hline \multirow[t]{8}{*}{4.} & [ázà $]$ & $\overline{Y B}$ & 126 & 134 & 138 & 133 & 150 & 126 & 116 & 103 & 115 & 160 \\
\hline & & IK & 123 & 130 & 138 & 130 & 120 & 126 & 112 & 87 & 108 & 130 \\
\hline & * & HS & 134 & 189 & 189 & 171 & 210 & 164 & 116 & 103 & 128 & 200 \\
\hline & & $\mathrm{FR}_{1}$ & 245 & 252 & 252 & 250 & 150 & 245 & 189 & 173 & 202 & 190 \\
\hline & & $\mathrm{FR}_{2}$ & 189 & 225 & 231 & 215 & 140 & 238 & 146 & 123 & 169 & 130 \\
\hline & * & $\mathrm{FR}_{3}$ & 150 & 150 & 150 & 150 & 80 & 138 & 126 & 109 & 124 & 120 \\
\hline & & $\mathrm{CH}_{1}$ & 126 & 138 & 138 & 134 & 100 & 126 & 109 & 97 & 111 & 160 \\
\hline & & $\mathrm{CH}_{2}$ & 173 & 178 & 178 & 176 & 160 & 178 & 164 & 146 & 163 & 80 \\
\hline
\end{tabular}




\begin{tabular}{|c|c|c|c|c|c|c|c|c|c|c|c|c|}
\hline \multirow{2}{*}{$\begin{array}{l}\text { SER. } \\
\text { No. }\end{array}$} & \multirow[t]{2}{*}{ WORDS } & \multirow{2}{*}{$\begin{array}{l}\text { SPEAK- } \\
\text { ERS } \\
\end{array}$} & \multicolumn{3}{|c|}{ FIRST SYLLABLE } & \multirow[b]{2}{*}{$\mathrm{F}_{0} \mathrm{~m}$} & \multirow{2}{*}{\begin{tabular}{|l} 
DURA \\
-TION \\
\end{tabular}} & \multicolumn{3}{|c|}{ SECOND SYLABLE } & \multirow[b]{2}{*}{$\mathrm{F}_{0} \mathrm{~m}$} & \multirow{2}{*}{$\begin{array}{l}\text { DURA } \\
\text {-TION } \\
\end{array}$} \\
\hline & & & $\mathrm{F}_{0} \mathrm{i}$ & $\overline{F_{0} 2 / 3}$ & $\overline{F_{0} f}$ & & & $F_{0} i$ & $\mathrm{~F}_{0} 2 / 3$ & $\mathrm{~F}_{0} f$ & & \\
\hline 5. & {$[\zeta k \grave{a}]$} & $\overline{\mathrm{YB}}$ & 123 & 123 & 126 & 124 & 120 & 126 & 112 & 103 & 114 & 110 \\
\hline & & IK & 103 & 130 & 130 & 121 & 120 & 130 & 116 & 89 & 112 & 80 \\
\hline & & HS & 150 & 189 & 195 & 178 & 130 & 200 & 142 & 123 & 155 & 200 \\
\hline & & $\mathrm{FR}_{1}$ & 245 & 267 & 275 & 262 & 110 & 275 & 206 & 189 & 223 & 80 \\
\hline & * & $\mathrm{FR}_{2}$ & 206 & 245 & 260 & 237 & 110 & 225 & 138 & 134 & 166 & 150 \\
\hline & & $\mathrm{FR}_{3}$ & 138 & 150 & 150 & 146 & 60 & 138 & 112 & 97 & 116 & 170 \\
\hline & & $\mathrm{CH}_{1}$ & 138 & 138 & 138 & 138 & 110 & 134 & 116 & 94 & 115 & 130 \\
\hline & * & $\mathrm{CH}_{2}$ & 178 & 178 & 184 & 180 & 80 & 159 & 142 & 116 & 139 & 110 \\
\hline
\end{tabular}

\begin{tabular}{|c|c|c|c|c|c|c|c|c|c|c|c|c|}
\hline \multirow{2}{*}{$\begin{array}{l}\text { SER. } \\
\text { No. }\end{array}$} & \multirow[t]{2}{*}{ WORDS } & \multirow{2}{*}{$\begin{array}{l}\text { SPEAK- } \\
\text { ERS }\end{array}$} & \multicolumn{3}{|c|}{ | FIRST SYLLABLE } & \multirow[b]{2}{*}{$\mathrm{F}_{0} \mathrm{~m}$} & \multirow{2}{*}{\begin{tabular}{|l} 
DURA \\
-TION \\
\end{tabular}} & \multicolumn{3}{|c|}{ SECOND SYLABLE } & \multirow[b]{2}{*}{$\mathrm{F}_{0} \mathrm{~m}$} & \multirow{2}{*}{\begin{tabular}{|l} 
DURA \\
-TION \\
\end{tabular}} \\
\hline & & & $F_{0^{i}}$ & $\mathrm{~F}_{0} 2 / 3$ & $F_{0} f$ & & & $F_{0^{i}}$ & $\mathrm{~F}_{0} 2 / 3$ & $F_{0} f$ & & \\
\hline \multirow[t]{8}{*}{6.} & $\overline{[a ́ k \delta]}$ & $\overline{Y B}$ & 116 & 126 & 116 & 119 & 140 & 126 & 116 & 103 & 115 & 110 \\
\hline & & IK & 123 & 130 & 130 & 128 & 100 & 126 & 97 & 87 & 103 & 120 \\
\hline & * & HS & 142 & 184 & 195 & 174 & 160 & 200 & 159 & 126 & 162 & 170 \\
\hline & & $\mathrm{FR}_{1}$ & 231 & 238 & 238 & 236 & 120 & 238 & 189 & 130 & 192 & 130 \\
\hline & $?$ & $\mathrm{FR}_{2}$ & 195 & 225 & 238 & 219 & 80 & 212 & 150 & 146 & 169 & 120 \\
\hline & & $\mathrm{FR}_{3}$ & 126 & 138 & 134 & 133 & 80 & 134 & 126 & 116 & 125 & 100 \\
\hline & & $\mathrm{CH}_{1}$ & 126 & 126 & 130 & 127 & 80 & 138 & 116 & 97 & 117 & 140 \\
\hline & & $\mathrm{CH}_{2}$ & 164 & 168 & 168 & 167 & 110 & 200 & 150 & 123 & 158 & 140 \\
\hline
\end{tabular}

\begin{tabular}{|c|c|c|c|c|c|c|c|c|c|c|c|c|}
\hline \multirow{2}{*}{$\begin{array}{l}\text { SER. } \\
\text { No. }\end{array}$} & \multirow[t]{2}{*}{ WORDS } & \multirow{2}{*}{$\begin{array}{l}\text { SPEAK- } \\
\text { ERS } \\
\end{array}$} & \multicolumn{3}{|c|}{ | FIRST SYLLABLE } & \multirow[b]{2}{*}{$\mathrm{F}_{0} \mathrm{~m}$} & \multirow{2}{*}{$\begin{array}{l}\text { DURA } \\
\text {-TION } \\
\end{array}$} & \multicolumn{3}{|c|}{ SECOND SYLABLE } & \multirow[b]{2}{*}{$\mathrm{F}_{0} \mathrm{~m}$} & \multirow{2}{*}{\begin{tabular}{|l} 
DURA \\
-TION \\
\end{tabular}} \\
\hline & & & $\overline{F_{0}}$ & $\overline{F_{0} 2 / 3}$ & $\overline{F_{0} f}$ & & & $\overline{F_{0}}{ }^{i}$ & $\mathrm{~F}_{0} 2 / 3$ & $\mathrm{~F}_{0} \mathrm{f}$ & & \\
\hline 7. & {$\left[e^{\prime} b \grave{b}\right]$} & $\overline{\mathrm{YB}}$ & 126 & 130 & 130 & 129 & 120 & 116 & 103 & 97 & 105 & 160 \\
\hline & * & IK & 146 & 154 & 154 & 151 & 190 & 119 & 119 & 123 & 120 & 160 \\
\hline & & HS & 146 & 178 & 178 & 167 & 120 & 150 & 119 & 103 & 124 & 180 \\
\hline & * & $\mathrm{FR}_{1}$ & 245 & 252 & 267 & 255 & 160 & 212 & 212 & 206 & 210 & 190 \\
\hline & * & $\mathrm{FR}_{2}$ & 225 & 252 & 275 & 251 & 170 & 245 & 189 & 146 & 193 & 250 \\
\hline & & $\mathrm{FR}_{3}$ & 173 & 195 & 195 & 188 & 110 & 189 & 154 & 112 & 152 & 120 \\
\hline & & $\mathrm{CH}_{1}$ & 123 & 126 & 123 & 124 & 130 & 138 & 123 & 116 & 126 & 210 \\
\hline & & $\mathrm{CH}_{2}$ & 195 & 195 & 195 & 195 & 200 & 146 & 138 & 138 & 141 & 120 \\
\hline
\end{tabular}




\section{REFERENCES}

Amayo, A.M. 1976. "A generative Edo phonology." Unpublished Doctoral Thesis, University of Ibadan, Ibadan, Nigeria.

Dojio, L.A. 1978. "Analysis instrumentales et perceptives des réalisations tonales du yoruba." Thèse de 3e Cycle, Université des Sciences Humaines, Strasbourg, France.

Hombert, J-M. 1976. "Perception of tones on bisyllabic nouns in Yoruba." In Larry M. Hyman, Russell G. Schuh, and Leon C. Jacobson (eds.), Papers in African Linguistics in Honor of Wm. E. Welmers, pp. 109-121. Studies in African Linguistics, Supplement 6. Los Angeles: UCLA African Studies Center.

Hyman, L.M. 1973. "The role of consonant types in natural tonal assimilations." In Larry M. Hyman (ed.), Consonant Types and Tone, pp. 153-179. Southern California Occasional Papers in Linguistics, No.I. Los Angeles: University of Southern California Linguistics Program.

Hyman, L.M. 1975. Phonology: Theory and Analysis. New York: Holt, Rinehart and Winston.

Lhote, E., J.M. Diaz de Leon, S. Vinter, and V.E. Omozuwa. 1986. "Mise en évidence de fonctions d'ancrage et de déclenchement en perception de parole." 15 e journées d'études sur la aasole. Groupement des Acousticiens de Langue Française, pp. 129-133. Aix-en Provence.

Omozuwa, V.E. 1987a. "L'edo: approches phonologiques, acoustiques, et perceptuelles du système phonémique et du système tonémique." Unpublished Doctoral Thesis, Université de Franche-Comté, Besançon, France.

Omozuwa, V.E. 1987b. "Les spécificités du relief tonal en edo: contribution à l'étude du 'downdrift' et du 'downstep'". Annales Litteraires de l'Université de Besançon 353:177-201.

Wescott, R.W. 1962. A Bini Grammar. Part I. Phonology. East Lansing, MI: African Studies Center, Michigan State University.

Wescott, R.W. 1965. "Speech-tempo and the phonemics of Bini." Journal of African Languages 4/3:182-190. 